Article

\title{
Selective hydrogenation of benzene to cyclohexene over nanocomposite $\mathrm{Ru}-\mathrm{Mn} / \mathrm{ZrO}_{2}$ catalysts
}

\author{
SUN Haijie, JIANG Houbing, LI Shuaihui, WANG Hongxia, PAN Yajie, DONG Yingying, \\ LIU Shouchang, LIU Zhongyi*
}

College of Chemistry and Molecular Engnineering, Zhengzhou University, Zhengzhou 450001, Henan, China

\section{A R T I C L E I N F O}

\section{Article history:}

Received 10 October 2012

Accepted 20 November 2012

Published 20 April 2013

\section{Keywords:}

Benzene

Selective hydrogenation

Cyclohexene

Ruthenium

Manganese

Zirconia

Zinc

\section{Introduction}

The production of nylon- 6 and nylon- 66 from benzene and cyclohexene has attracted much attention because it is a safe, environmentally benign, and atomic economic process [1-4]. Hydrogenation of benzene to cyclohexene is thermodynamically favored [5]. The development of a catalyst with high cyclohexene selectivity in the hydrogenation of benzene is therefore important for this technology.

Second metals or metal oxides could significantly improve the cyclohexene selectivities and yields of Ru-based catalysts. Xie et al. [6] prepared an $\mathrm{Ru}-\mathrm{B} / \mathrm{SiO}_{2}$ catalyst by impregnation and chemical reduction methods, and found that the activity and cyclohexene selectivity of this catalyst in $\mathrm{H}_{2}$ reduction of benzene were better than those of an $\mathrm{Ru} / \mathrm{SiO}_{2}$ catalyst with the same Ru loading. They also revealed that the B was present in two forms, namely oxidized and elemental B species, and modification of their hydrophilicities on the surface of the $\mathrm{Ru}-\mathrm{B} / \mathrm{SiO}_{2}$ catalyst gave this catalyst high activity and high cyclohexene selectivity. Liu et al. [7] prepared an $\mathrm{Ru}-\mathrm{La}-\mathrm{B} / \mathrm{ZrO}_{2}$ catalyst using a chemical reduction method and obtained a cyclohexene yield of $53.2 \%$ and a corresponding cyclohexene selectivity of $61.9 \%$. They confirmed that the La in this catalyst existed as $\mathrm{La}_{2} \mathrm{O}_{3}$. Fan et al. [8] prepared an $\mathrm{Ru}-\mathrm{Co}-\mathrm{B} / \gamma-\mathrm{Al}_{2} \mathrm{O}_{3}$ catalyst using an impregnation reduction method, and achieved a cyclohexene yield of $28.8 \%$ without any additives. They discovered that the Co in this catalyst was present as an oxide. Liu et al. [9] prepared an Ru-Ce/SBA-15 catalyst using a "two-solvent" im-

\footnotetext{
*Corresponding author. Tel: +86-371-67783384; E-mail: liuzhongyi@zzu.edu.cn

This work was supported by the National Nature Science Foundation of China (21273205), the Innovation Found for Technology Based Firms of China (10C26214104505), the China Postdoctoral Science Fundation (2012M511125), and the Scientific Research Foundation of Graduate School of Zhengzhou University.
} 
pregnation method and achieved a cyclohexene yield of 53.8\% over the catalyst with an optimum $\mathrm{Ce} / \mathrm{Ru}$ molar ratio of 0.25 . They found that the Ce existed as a Ce(III) species. These studies provide a good basis for the development of catalysts and catalytic systems for the selective hydrogenation of benzene to cyclohexene.

In previous work, we developed nano-amorphous $\mathrm{Ru}-\mathrm{M}-\mathrm{B} / \mathrm{ZrO}_{2}$ ( $\mathrm{M}=\mathrm{Zn}, \mathrm{Co}, \mathrm{Fe}, \mathrm{La}$ ) catalysts with $\mathrm{Ru}$ loadings less than one-third those of industrial Ru-Zn catalysts and obtained a cyclohexene selectivity of $78.8 \%$ at a benzene conversion of $59.6 \%$. This was much better than the cyclohexene selectivity of $80 \%$ at a benzene conversion of $40 \%$ obtained over industrial $\mathrm{Ru}-\mathrm{Zn}$ catalysts [10-12]. We developed monolayer dispersed Ru-Si-M (M = Zn, Mn, Fe, Ce, La) catalysts and achieved a cyclohexene selectivity of $80 \%$ at a benzene conversion of $60 \%$. The catalysts were used in a commercial unit and were shown to be economical, safe, and environmentally friendly. We have applied for national patents for these catalysts $[13,14]$. In this work, we prepared a series of Ru-Mn catalysts with different Mn contents, investigated the influence of different Mn contents on the performance of the Ru catalysts in selective hydrogenation of benzene to cyclohexene, and determined the role of the Mn promoter. The stability and reusability of the $\mathrm{Ru}-\mathrm{Mn} / \mathrm{ZrO}_{2}$ catalyst with an optimum Mn content of $5.4 \%$ were also investigated.

\section{Experimental}

\subsection{Catalyst preparation}

$\mathrm{RuCl}_{3} \cdot \mathrm{H}_{2} \mathrm{O}\left(9.75 \mathrm{~g}\right.$ ) and the desired amount of $\mathrm{MnSO}_{4} \cdot \mathrm{H}_{2} \mathrm{O}$ were dissolved in $200 \mathrm{ml}$ of $\mathrm{H}_{2} \mathrm{O}$ with agitation. A $10 \% \mathrm{NaOH}$ solution was added to the stirred solution. After the reaction was complete, the mixture was filtrated and the black precipitate was washed three times with distilled water. This black precipitate was then dispersed in $400 \mathrm{ml}$ of a $5 \% \mathrm{NaOH}$ solution and charged in a 1-L Teflon-lined autoclave. The reduction conditions were as follows: $\mathrm{H}_{2}$ pressure $5 \mathrm{MPa}$, temperature $150{ }^{\circ} \mathrm{C}$, stirring rate $800 \mathrm{r} / \mathrm{min}$, and time $3 \mathrm{~h}$. The obtained black powder was washed with distilled water until neutrality was achieved, and subsequently vacuum-dried, giving the desired Ru-Mn catalyst. The catalyst was divided into two portions. One portion was used for activity tests and the other was used for catalyst characterization. This ensured the catalysts with different $\mathrm{Mn}$ contents had the same $\mathrm{Ru}$ contents. The amounts of $\mathrm{MnSO}_{4} \cdot \mathrm{H}_{2} \mathrm{O}$ were adjusted to give catalysts with different Mn contents, denoted by $\operatorname{Ru}-\operatorname{Mn}(x)$, where $x$ denotes the weight percentage of $\mathrm{Mn}$ in the catalyst, determined by atomic absorption spectrometry. Ru-Mn catalysts prepared using different Mn precursors were obtained according to the above procedure, except that $\mathrm{MnSO}_{4} \cdot \mathrm{H}_{2} \mathrm{O}$ was replaced by equal molar amounts of $\mathrm{Mn}\left(\mathrm{NO}_{3}\right)_{2}$ or $\mathrm{MnCl}_{2}$.

\subsection{Catalyst characterization}

The weight percentages of $\mathrm{Mn}$ and the concentration of $\mathrm{Mn}^{2+}$ and $\mathrm{Zn}^{2+}$ were analyzed by inductively coupled plas- ma-atomic emission spectroscopy (ICP-AES) on an ICAT 6000 SERIES instrument of Heme Electron corporation. X-ray diffraction (XRD) patterns were acquired using a PANalytcal $\mathrm{X}^{\prime}$ Pert PRO instrument with $\mathrm{Cu} K_{\alpha}(\lambda=0.1541 \mathrm{~nm})$ radiation and a scan range of $2 \theta=5^{\circ}-90^{\circ}$ in steps of $0.03^{\circ}$. Transmission electron microscopy (TEM) was performed using a JEOL JEM-2100 instrument. $\mathrm{N}_{2}$ physisorption (Brunauer-Emmett-Teller method) was determined using a Quantachrome Nova 100e apparatus. The compositions of the catalysts were determined by X-ray fluorescence (XRF), using a Bruker S4 Pioneer instrument. Auger electron spectroscopy (AES) of the Zn LMM transitions was performed using a ULVAC PHI-700 nanoscanning Auger system with an on-axis scanning Ar-ion gun and a cylindrical mirror energy analyzer. The energy resolution was $0.1 \%$. The background pressure of the analysis room was less than $5.2 \times 10^{-7} \mathrm{~Pa}$. The standard sample was $\mathrm{SiO}_{2} / \mathrm{Si}$.

\subsection{Activity tests}

The selective hydrogenation of benzene was performed in a 1-L Hastelloy-lined autoclave. A sample of Ru-Mn catalyst, $9.8 \mathrm{~g}$ of $\mathrm{ZrO}_{2}$, and $49.2 \mathrm{~g}$ of $\mathrm{ZnSO}_{4}$ were charged in the autoclave. Heating was begun with an $\mathrm{H}_{2}$ pressure of $5 \mathrm{MPa}$ and a stirring rate of $800 \mathrm{r} / \mathrm{min}$. Benzene $(140 \mathrm{ml})$ was fed into the system and the stirring rate was increased to $1400 \mathrm{r} / \mathrm{min}$ to prevent diffusion effects when the temperature reached $150{ }^{\circ} \mathrm{C}$. The reaction process was monitored by taking small samples of the reaction mixture every $5 \mathrm{~min}$. The products were analyzed by gas chromatography using a GC-1690 gas chromatograph with a flame ionization detector (Hangzhou Kexiao Instrument Co., China). The benzene conversion and cyclohexene selectivity were calculated from the product concentration obtained using corrected peak area normalization. At the end of the reaction, the organic phase was removed using a separating funnel. The slurry containing the mixture of the catalyst and $\mathrm{ZrO}_{2}$ was reused, according to the above operations, without any additions. The catalysts after hydrogenation were denoted by $\mathrm{Ru}-\mathrm{Mn}(x) / \mathrm{ZrO}_{2}$, where $x$ is the weight percentage of $\mathrm{Mn}$ in the catalyst, determined by atomic absorption spectrometry. The $\mathrm{Ru}-\mathrm{Mn}(5.4 \%)$ catalyst without the addition of $\mathrm{ZrO}_{2}$ after hydrogenation was denoted by $\mathrm{Ru}-\mathrm{Mn}(5.4 \%) \mathrm{AH}$, where $\mathrm{AH}$ represents after hydrogenation.

\section{Results and discussion}

\subsection{Catalyst characterization results}

Figure 1 shows the XRD patterns of the $\mathrm{Ru}-\operatorname{Mn}(x)$ catalysts and the $\mathrm{Ru}-\mathrm{Mn}(x)$ catalysts with $\mathrm{ZrO}_{2}$ as a dispersant after hydrogenation. Figure 1(a) shows that all the $\mathrm{Ru}-\mathrm{Mn}(x)$ catalysts display the diffraction peaks of the hexagonal phases of metallic $\mathrm{Ru}$ (JCPDS 01-070-0274) at $2 \theta=38.5^{\circ}, 42.3^{\circ}, 44.0^{\circ}, 58.3^{\circ}, 69.2^{\circ}$, $78.4^{\circ}$, and $38.5^{\circ}$. The Ru-Mn(8.0\%) and Ru-Mn(10.8\%) catalysts show the diffraction peaks of $\mathrm{Mn}_{3} \mathrm{O}_{4}$ (JCPDS 00-001-1127) at $2 \theta=18.0^{\circ}, 32.7^{\circ}, 36.1^{\circ}, 58.9^{\circ}$, and $69.3^{\circ}$. Morales et al. [15] confirmed that the $\mathrm{Mn}$ in a $\mathrm{Co}-\mathrm{Mn} / \mathrm{TiO}_{2}$ catalyst reduced below 


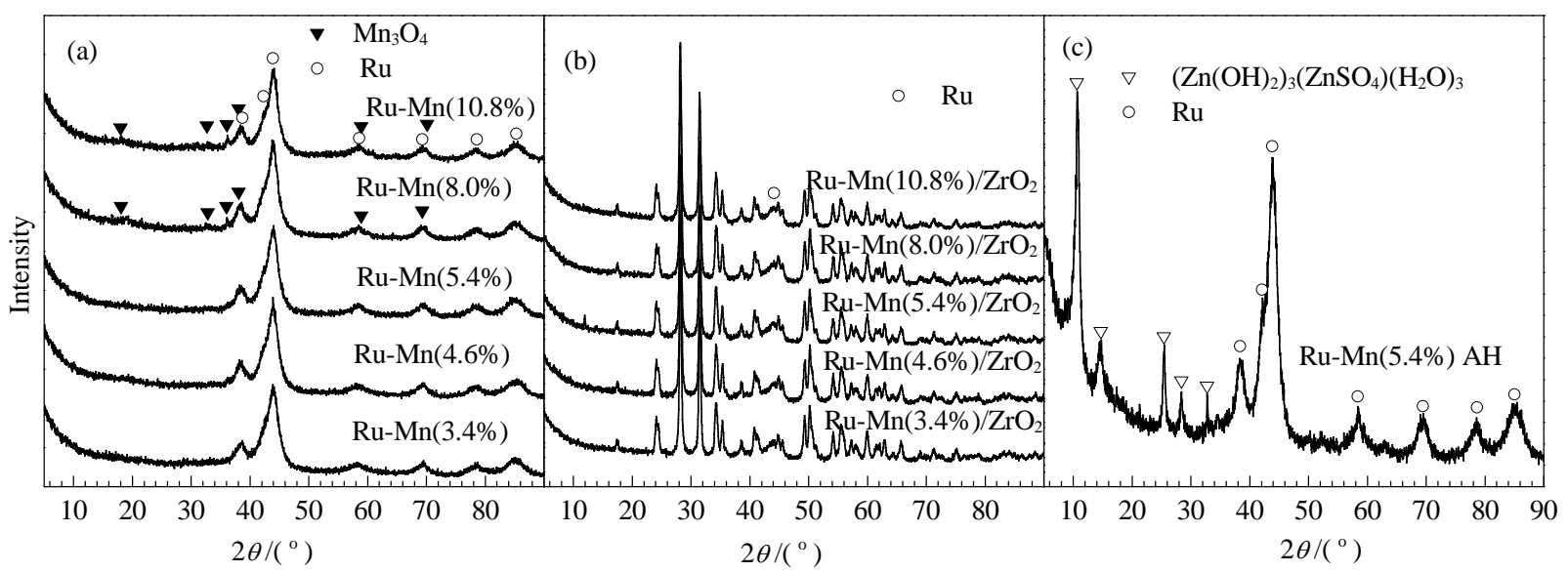

Fig. 1. XRD patterns of Ru-Mn(x) (a), Ru-Mn(x)/ZrO 2 (b), and Ru-Mn(5.4\%) AH (c) samples. Ru-Mn(x) denotes Ru-Mn catalysts, where $x$ is the mass percentage of $\mathrm{Mn}$ in the catalyst; $\mathrm{Ru}-\mathrm{Mn}(x) / \mathrm{ZrO}{ }_{2}$ is $\mathrm{Ru}-\mathrm{Mn}(x)$ catalyst with $\mathrm{ZrO}_{2}$ as a dispersant after hydrogenation; $\mathrm{Ru}-\mathrm{Mn}(x) \mathrm{AH}$ is $\mathrm{Ru}-\mathrm{Mn}(x)$ catalyst without $\mathrm{ZrO}_{2}$ after hydrogenation.

Table 1

Textural properties and crystallite sizes of $\mathrm{Ru}-\mathrm{Mn}(x)$ catalysts.

\begin{tabular}{lcccc}
\hline Catalyst & $\begin{array}{c}\text { Surface area } \\
\left(\mathrm{m}^{2} / \mathrm{g}\right)\end{array}$ & $\begin{array}{c}\text { Pore diame- } \\
\text { ter }(\mathrm{nm})\end{array}$ & $\begin{array}{c}\text { Pore volume } \\
(\mathrm{ml} / \mathrm{g})\end{array}$ & $\begin{array}{c}\text { Crystallite size } \\
(\mathrm{nm})\end{array}$ \\
\hline $\mathrm{Ru}-\mathrm{Mn}(3.4 \%)$ & 72 & 12.2 & 0.22 & 3.7 \\
$\mathrm{Ru}-\mathrm{Mn}(4.6 \%)$ & 71 & 11.8 & 0.21 & 4.3 \\
$\mathrm{Ru}-\mathrm{Mn}(5.4 \%)$ & 62 & 11.6 & 0.18 & 3.8 \\
$\mathrm{Ru}-\mathrm{Mn}(8.0 \%)$ & 68 & 9.4 & 0.16 & 4.0 \\
$\mathrm{Ru}-\mathrm{Mn}(10.8 \%)$ & 56 & 11.2 & 0.16 & 4.5 \\
\hline
\end{tabular}

$300{ }^{\circ} \mathrm{C}$ existed as $\mathrm{Mn}_{3} \mathrm{O}_{4}$. The reduction temperature was only $150{ }^{\circ} \mathrm{C}$. These results prompted us to suggest that the $\mathrm{Mn}$ in the $\mathrm{Ru}-\mathrm{Mn}(x)$ catalysts was mainly present as $\mathrm{Mn}_{3} \mathrm{O}_{4}$. When the $\mathrm{Mn}$ contents were in the range $3.4 \%-5.4 \%$, the diffraction peaks of $\mathrm{Mn}_{3} \mathrm{O}_{4}$ were not observed in the XRD patterns of the $\mathrm{Ru}-\mathrm{Mn}(x)$ catalysts as a result of the low amounts and small crystallites of $\mathrm{Mn}_{3} \mathrm{O}_{4}$.

Table 1 presents the Ru crystallite sizes of the catalysts calculated from the strongest peak broadening at $2 \theta=44^{\circ}$ using the Scherrer equation. As can be seen, the Ru crystallite sizes of the $\mathrm{Ru}-\mathrm{Mn}(x)$ catalysts were distributed in the narrow range 3.7-4.5 nm, indicating that the introduction of $\mathrm{Mn}_{3} \mathrm{O}_{4}$ had little effect on the Ru crystallite sizes.

Figure $1(\mathrm{~b})$ shows that all the $\mathrm{Ru}-\mathrm{Mn}(x) / \mathrm{ZrO}_{2}$ catalysts after hydrogenation have the weak diffraction peaks of metallic $\mathrm{Ru}$ at $2 \theta=44.0^{\circ}$, indicating small Ru crystallite sizes. All the other
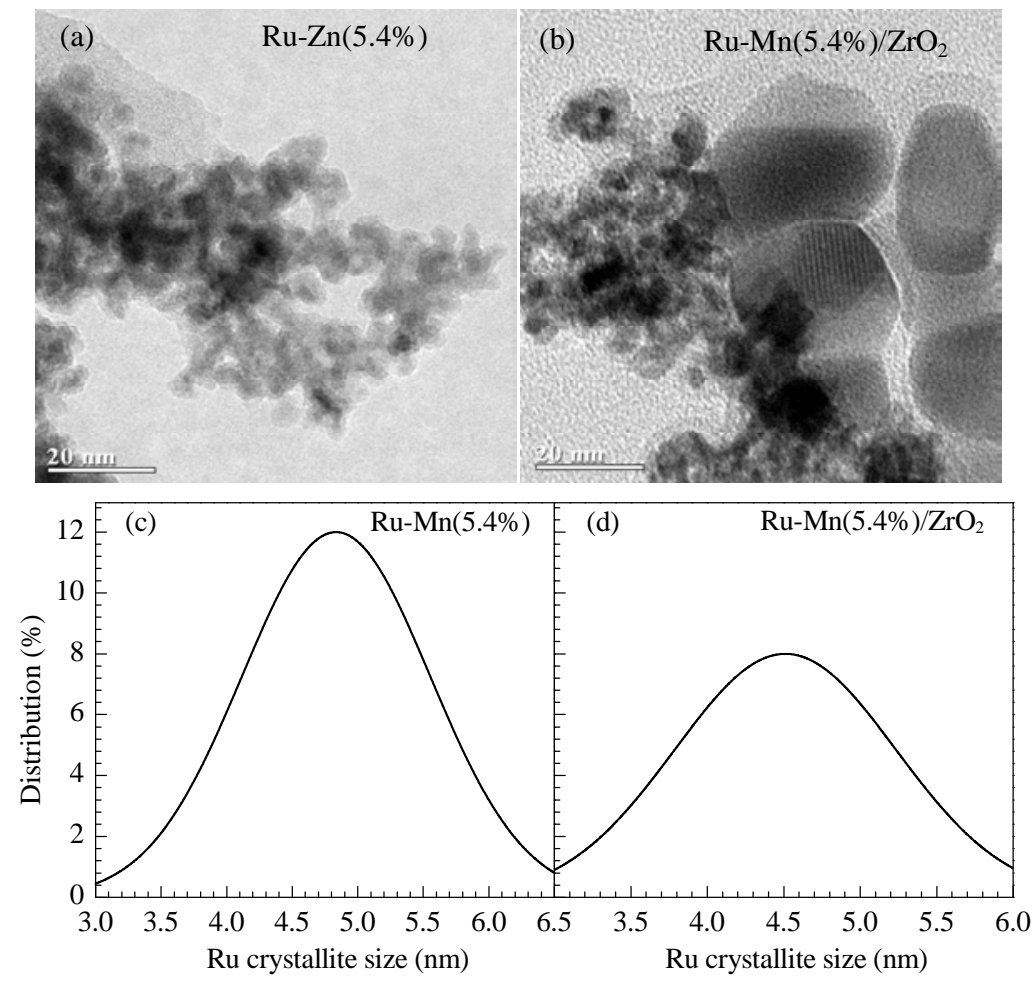

Fig. 2. TEM images (a, b) and Ru crystallite size distributions (c, d) of $\mathrm{Ru}-\mathrm{Mn}(5.4 \%)$ and $\mathrm{Ru}-\mathrm{Mn}(5.4 \%) / \mathrm{ZrO}_{2}$. 
diffraction peaks corresponded to the monoclinic phases of $\mathrm{ZrO}_{2}$ (JCPDS 00-024-1165). Figure 1(c) shows that the $\mathrm{Ru}-\mathrm{Zn}(5.4 \%)$ catalyst without the addition of $\mathrm{ZrO}_{2}$ after hydrogenation displayed not only the diffraction peaks of metallic $\mathrm{Ru}$ but also the diffraction peaks of the $\left[\mathrm{Zn}(\mathrm{OH})_{2}\right]_{3}\left(\mathrm{ZnSO}_{4}\right)\left(\mathrm{H}_{2} \mathrm{O}\right)_{3}$ salt (JCPDS 01-078-0247). This indicated that the $\left[\mathrm{Zn}(\mathrm{OH})_{2}\right]_{3}\left(\mathrm{ZnSO}_{4}\right)\left(\mathrm{H}_{2} \mathrm{O}\right)_{3}$ salt had formed on the surface of the $\mathrm{Ru}-\mathrm{Mn}(5.4 \%)$ catalyst after hydrogenation in the presence of $\mathrm{ZnSO}_{4}$. However, the diffraction peaks of this salt were not observed on the surface of the $\operatorname{Ru}-\operatorname{Mn}(x)$ catalysts after hydrogenation with the addition of $\mathrm{ZrO}_{2}$, suggesting that this salt was highly dispersed on the surface of the $\operatorname{Ru}-\operatorname{Mn}(x)$ catalysts and the $\mathrm{ZrO}_{2}$ dispersant. Xie et al. [16] confirmed that many salts could spontaneously disperse on the support surfaces.

Figure 2 shows the TEM images of the $\mathrm{Ru}-\mathrm{Mn}(5.4 \%)$ catalyst and the $\mathrm{Ru}-\mathrm{Mn}(5.4 \%)$ catalyst after hydrogenation, with $\mathrm{ZrO}_{2}$ as a dispersant, and the corresponding $\mathrm{Ru}$ crystallite size distributions. Figure 2(a) shows that the Ru-Mn(5.4\%) catalyst consisted of nanoscale spherical and ellipsoidal Ru crystallites. Figure 2(c) shows that the $\mathrm{Ru}$ crystallite size of the $\mathrm{Ru}-\mathrm{Mn}(5.4 \%)$ catalyst was concentrated at around $4.8 \mathrm{~nm}$, which was consistent with the XRD results. Figure 2 shows that the $\mathrm{ZrO}_{2}$ dispersant mainly consisted of $\mathrm{ZrO}_{2}$ crystallites of size about $20 \mathrm{~nm}$. The catalyst particles were separated and isolated by $\mathrm{ZrO}_{2}$ after the first hydrogenation, indicating that a suitable amount of $\mathrm{ZrO}_{2}$ could significantly suppress agglomeration, which could have occurred as a result of collisions among different catalyst particles under high agitation [17]. Figure 2(d) shows that the $\mathrm{Ru}$ crystallite sizes of the $\mathrm{Ru}-\mathrm{Mn}(5.4 \%) / \mathrm{ZrO}_{2}$ catalyst after hydrogenation were mainly distributed at around $4.5 \mathrm{~nm}$, which is much smaller than the crystallites of the $\mathrm{Ru}-\mathrm{Mn}(5.4 \%)$ catalyst before hydrogenation. This indicated that the $\mathrm{ZrO}_{2}$ played an important role in dispersing the catalyst particles.

Table 1 shows the textural properties of the $\operatorname{Ru}-\operatorname{Mn}(x)$ catalysts. As can be seen, the surface areas, pore volumes, and pore diameters generally decreased with the Mn content of the catalysts. Zhang et al. [18] found that the specific surface area of a Co-Mn/ $/ \mathrm{TiO}_{2}$ catalyst was less than that of $\mathrm{TiO}_{2}$, and they suggested that amorphous $\mathrm{MnO}_{x}$ was dispersed on the $\mathrm{TiO}_{2}$ surface and blocked some of the catalyst pores. Similarly, it is proposed that $\mathrm{Mn}_{3} \mathrm{O}_{4}$ was dispersed on the surface of the catalysts and could block some of the catalyst pores, resulting in decreases in the surface areas, pore volumes, and pore diameters. The textural properties of the $\mathrm{Ru}-\mathrm{Mn}(x)$ catalysts after hydrogenation were similar to that of $\mathrm{ZrO}_{2}$ because the mass ratio of $\mathrm{ZrO}_{2}$ to catalyst was 5:1 [19]. $\mathrm{N}_{2}$ physisorption studies of the $\mathrm{Ru}-\mathrm{Mn}(x) / \mathrm{ZrO}_{2}$ after hydrogenation were therefore not necessary.

Table 2 shows the compositions of the $\mathrm{Ru}-\mathrm{Mn}(x) / \mathrm{ZrO}_{2}$ and $\operatorname{Ru}-\operatorname{Mn}(x) \mathrm{AH}$, the concentrations of metallic ions in the aqueous phase, and the $\mathrm{pH}$ values of the aqueous phase at room temperature. The $\mathrm{Mn} / \mathrm{Ru}, \mathrm{Zn} / \mathrm{Ru}$, and $\mathrm{Zr} / \mathrm{Ru}$ atomic ratios clearly reflect the variations in the catalyst compositions before and after hydrogenation. $\mathrm{Ru}-\mathrm{Mn}(x)$ catalysts with different Mn contents were prepared using $\mathrm{MnSO}_{4} \cdot \mathrm{H}_{2} \mathrm{O}$ as the precursor. As can be seen from Table 2, the molar ratios of the $\mathrm{Ru}-\mathrm{Mn}(x) / \mathrm{ZrO}_{2}$ catalysts after hydrogenation were all 0.02 , indicating trace amounts of $\mathrm{Mn}$ in the $\mathrm{Ru}-\mathrm{Mn}(x) / \mathrm{ZrO}_{2}$ after hydrogenation. The $\mathrm{Zn} / \mathrm{Ru}$ atomic ratios of $\mathrm{Ru}-\mathrm{Mn}(x) / \mathrm{ZrO}_{2}$ after hydrogenation increased, and the concentrations of $\mathrm{Mn}^{2+}$ in the aqueous phase increased and the concentrations of $\mathrm{Zn}^{2+}$ decreased with Mn content. In particular, the colorless slurries after hydrogenation prompted us to propose that the Mn in the slurries existed as $\mathrm{Mn}^{2+}$. All of these results indicated that the $\mathrm{Mn}_{3} \mathrm{O}_{4}$ on the surfaces of the $\mathrm{Ru}-\mathrm{Mn}(x)$ catalysts had reacted with $\mathrm{ZnSO}_{4}$ to form a new $\mathrm{Zn}$ species and an $\mathrm{Mn}$ ( II ) species. The $\mathrm{Zn}$ species were chemisorbed on the Ru surfaces and the Mn( II) species were dissolved in the slurries. A trace amount of Mn was also detectable in the $\mathrm{Ru}-\mathrm{Mn}(5.4 \%)$ catalyst without the addition of $\mathrm{ZrO}_{2}$ after hydrogenation. Its $\mathrm{Zn} / \mathrm{Ru}$ molar ratio was similar to that with $\mathrm{ZrO}_{2}$. It was also found that the $\mathrm{S} / \mathrm{Ru}$ molar ratio for the catalyst without $\mathrm{ZrO}_{2}$ was 0.06 , which was consistent with the XRD results, and showed that the $\mathrm{Zn}$ species existed as the $\left[\mathrm{Zn}(\mathrm{OH})_{2}\right]_{3}\left(\mathrm{ZnSO}_{4}\right)\left(\mathrm{H}_{2} \mathrm{O}\right)_{3}$ salt. The addition of $\mathrm{ZrO}_{2}$ lowered the $\mathrm{S}$ contents of the $\mathrm{Ru}-\mathrm{Mn}(x)$ catalysts after hydrogenation to below the detection limit of the XRF instrument. All these results implied that the $\mathrm{Zn}$ species existed as the $\left[\mathrm{Zn}(\mathrm{OH})_{2}\right]_{3}\left(\mathrm{ZnSO}_{4}\right)\left(\mathrm{H}_{2} \mathrm{O}\right)_{3}$ salt. The amount of $\left[\mathrm{Zn}(\mathrm{OH})_{2}\right]_{3}\left(\mathrm{ZnSO}_{4}\right)\left(\mathrm{H}_{2} \mathrm{O}\right)_{3}$ salt increased with the $\mathrm{Mn}_{3} \mathrm{O}_{4}$ content, which resulted in an increase in the $\mathrm{Zn} / \mathrm{Ru}$ atomic ratio. It was concluded that the $\mathrm{Mn}_{3} \mathrm{O}_{4}$ was mainly present on the $\mathrm{Ru}$ surface because the $\mathrm{ZnSO}_{4}$ in the slurry could only react with $\mathrm{Mn}_{3} \mathrm{O}_{4}$ on the $\mathrm{Ru}$ surface, i.e., the $\left[\mathrm{Zn}(\mathrm{OH})_{2}\right]_{3}\left(\mathrm{ZnSO}_{4}\right)\left(\mathrm{H}_{2} \mathrm{O}\right)_{3}$ salt formed could only be chemisorbed on the Ru surface. Table 2 shows that the $\mathrm{pH}$ values of the aqueous solutions after hydro-

Table 2

Composition of $\mathrm{Ru}-\mathrm{Mn}(x) / \mathrm{ZrO}_{2}$ catalysts after hydrogenation and concentrations of the metallic ions in the aqueous phase as well as their $\mathrm{pH}$ values at room temperature.

\begin{tabular}{|c|c|c|c|c|c|c|c|}
\hline \multirow{2}{*}{ Sample } & \multirow{2}{*}{ Mn source } & \multicolumn{3}{|c|}{ Elemental ratio ${ }^{\mathrm{a}}(\mathrm{mol} / \mathrm{mol})$} & \multicolumn{2}{|c|}{ Ion concentration ${ }^{\mathrm{b}}(\mathrm{mol} / \mathrm{L})$} & \multirow{2}{*}{$\mathrm{pH}$ value ${ }^{\mathrm{c}}$} \\
\hline & & $\mathrm{Mn} / \mathrm{Ru}$ & $\mathrm{Zn} / \mathrm{Ru}$ & $\mathrm{Zr} / \mathrm{Ru}$ & $\mathrm{Zn}^{2+}$ & $\mathrm{Mn}^{2+}$ & \\
\hline $\mathrm{Ru}-\mathrm{Mn}(3.4 \%) / \mathrm{ZrO}_{2}$ & $\mathrm{MnSO}_{4}$ & 0.02 & 0.34 & 5.16 & 0.44 & $3.11 \times 10^{-3}$ & 5.6 \\
\hline $\mathrm{Ru}-\mathrm{Mn}(4.6 \%) / \mathrm{ZrO}_{2}$ & $\mathrm{MnSO}_{4}$ & 0.02 & 0.42 & 5.12 & 0.43 & $4.11 \times 10^{-3}$ & 5.4 \\
\hline $\mathrm{Ru}-\mathrm{Mn}(5.4 \%) / \mathrm{ZrO}_{2}$ & $\mathrm{MnSO}_{4}$ & 0.02 & 0.46 & 4.98 & 0.42 & $6.36 \times 10^{-3}$ & 6.0 \\
\hline $\mathrm{Ru}-\mathrm{Mn}(8.0 \%) / \mathrm{ZrO}_{2}$ & $\mathrm{MnSO}_{4}$ & 0.02 & 0.52 & 5.07 & 0.41 & $9.82 \times 10^{-3}$ & 5.9 \\
\hline $\mathrm{Ru}-\mathrm{Mn}(10.8 \%) / \mathrm{ZrO}_{2}$ & $\mathrm{MnSO}_{4}$ & 0.02 & 0.55 & 5.26 & 0.37 & $1.0 \times 10^{-2}$ & 6.2 \\
\hline $\mathrm{Ru}-\mathrm{Mn}(5.2 \%) / \mathrm{ZrO}_{2}$ & $\mathrm{Mn}\left(\mathrm{NO}_{3}\right)_{2}$ & 0.01 & 0.45 & 5.04 & - & - & - \\
\hline $\mathrm{Ru}-\mathrm{Mn}(5.6 \%) / \mathrm{ZrO}_{2}$ & $\mathrm{MnCl}_{2}$ & 0.02 & 0.47 & 5.17 & - & - & - \\
\hline Ru-Mn(5.4\%) AH & $\mathrm{MnSO}_{4}$ & 0.02 & 0.49 & 0 & - & - & 6.0 \\
\hline
\end{tabular}

a Measured by X-ray fluorescence (XRF).

${ }^{\mathrm{b}}$ Determined by ICP-AES. 


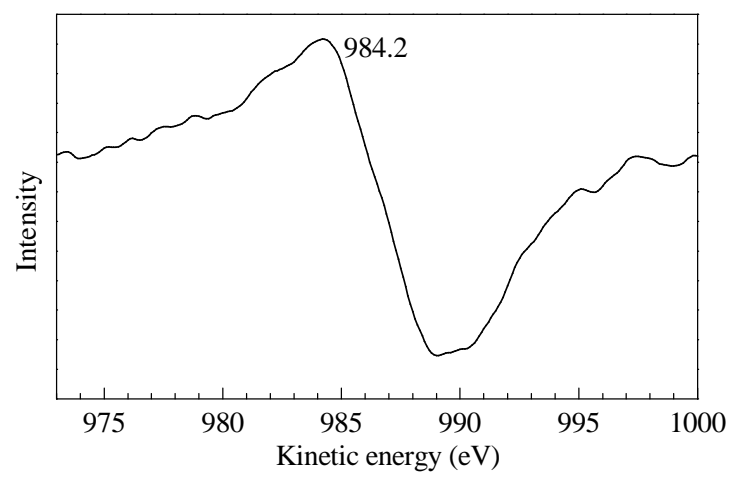

Fig. 3. AES Zn LMM spectrum of $\mathrm{Ru}-\mathrm{Mn}(5.4 \%) / \mathrm{ZrO}_{2}$ sample.

genation generally increased with $\mathrm{Mn}$ content of the catalyst. More $\mathrm{Mn}_{3} \mathrm{O}_{4}$ reacted with more $\mathrm{ZnSO}_{4}$ to form the $\left[\mathrm{Zn}(\mathrm{OH})_{2}\right]_{3}\left(\mathrm{ZnSO}_{4}\right)\left(\mathrm{H}_{2} \mathrm{O}\right)_{3}$ salt, resulting in a decrease in the $\mathrm{Zn}^{2+}$ concentrations. The degree of hydrolysis of $\mathrm{ZnSO}_{4}$ therefore decreased and the $\mathrm{pH}$ values of the aqueous solutions increased. The molar ratios of the $\mathrm{Ru}-\mathrm{Mn}(x) / \mathrm{ZrO}_{2}$ catalysts after hydrogenation were stable, at around 5.00, as a result of the fixed amounts of $\mathrm{ZrO}_{2}$.

$\mathrm{Ru}-\mathrm{Mn}(x)$ catalysts were prepared from different precursors, namely $\mathrm{MnSO}_{4}, \mathrm{Mn}\left(\mathrm{NO}_{3}\right)_{2}$, and $\mathrm{MnCl}_{2}$, in equimolar quantities. The Mn mass percentages in the catalysts, measured by atomic absorption spectroscopy, were 5.4\%, 5.2\%, and 5.6\%, respectively. Table 2 shows that the $\mathrm{Mn} / \mathrm{Ru}, \mathrm{Zn} / \mathrm{Ru}$, and $\mathrm{Zr} / \mathrm{Ru}$ atomic ratios of the $\mathrm{Ru}-\mathrm{Mn}(x) / \mathrm{ZrO}_{2}$ catalysts after hydrogenation were similar, indicating similar chemical compositions of the $\mathrm{Ru}-\mathrm{Mn}(x) / \mathrm{ZrO}_{2}$ catalysts after hydrogenation.

The Zn(II) species chemisorbed on the Ru surface played an important role in improving the cyclohexene selectivities of the $\mathrm{Ru}$ catalysts [20-23]. However, there are different opinions about the $\mathrm{Zn}$ valence. Wang et al. [20] characterized $\mathrm{Ru}-\mathrm{Zn} / m-\mathrm{ZrO}_{2}$ catalysts using XPS and found that the $\mathrm{Zn} 2 p_{3 / 2}$ binding energy (BE) of the $\mathrm{Zn}$ in the catalyst was close to that of metallic $\mathrm{Zn}$. They suggested that chemisorbed $\mathrm{Zn}^{2+}$ cations could be reduced to metallic Zn by the hydrogen atoms that spilled from the surface of the Ru catalyst. Yuan et al. [21] and He et al. [22] also indicated that $\mathrm{Zn}$ atoms could be introduced into $\mathrm{Ru}$-based catalysts by the reduction of $\mathrm{Zn}^{2+}$, based on XPS results. However, Struijk et al. [24] indicated that the $\mathrm{Zn}^{2+}$ in the adsorption of $\mathrm{ZnSO}_{4}$ could not be reduced on the surface of an $\mathrm{Ru}$ catalyst, also on the basis of XPS results. An important reason for such differences is the closeness of the $\mathrm{Zn} 2 p_{3 / 2}$ BEs corresponding to $\mathrm{Zn}(\mathrm{II})$ and metallic $\mathrm{Zn}$. It is therefore very difficult to assess the valences of $\mathrm{Zn}$ based on the $\mathrm{Zn} 2 p_{3 / 2}$ BEs [25]. This drawback can be overcome by using the Zn LMM Auger transition, as the Auger shift between $\mathrm{Zn}$ (II) and metallic $\mathrm{Zn}$ is higher than $4.6 \mathrm{eV}$ [26]. Figure 3 shows the AES Zn LMM spectra of the $\mathrm{Ru}-\mathrm{Mn}(5.4 \%)$ catalyst with $\mathrm{ZrO}_{2}$ after hydrogenation. The spectra were recorded after $\mathrm{Ar}^{+}$sputtering for 1 min to avoid interruptions of the surface oxidation of the catalyst. As can be seen, the kinetic energy of Zn LMM for $\mathrm{Ru}-\mathrm{Mn}(5.4 \%) / \mathrm{ZrO}_{2}$ after hydrogenation was $984.2 \mathrm{eV}$, which was in agreement with that of $\mathrm{Zn}(\mathrm{II})$ species $[27,28]$. This was also consistent with the XRD result that the $\mathrm{Zn}$ species existed as the $\left[\mathrm{Zn}(\mathrm{OH})_{2}\right]_{3}\left(\mathrm{ZnSO}_{4}\right)\left(\mathrm{H}_{2} \mathrm{O}\right)_{3}$ salt. This also indicates that the $\mathrm{Zn}$ species chemisorbed on the $\mathrm{Ru}$ surface were still present as $\mathrm{Zn}^{2+}$ even under reaction conditions of $150{ }^{\circ} \mathrm{C}$ and an $\mathrm{H}_{2}$ pressure of 5.0 $\mathrm{MPa}$. The AES measurements did not identify any additional contributions from metallic Zn (commonly appearing in the 991-995 eV range), indicating that the $\mathrm{Zn}^{2+}$ chemisorbed on the Ru surface could not be reduced to metallic $\mathrm{Zn}$. The results in Table 2 show that the aqueous solutions after hydrogenation at room temperature were acidic, as a result of the hydrolysis of $\mathrm{ZnSO}_{4}$. It is well known that higher temperatures favor hydrolysis. This means that the acidity of the liquid phase is much higher at a reaction temperature of $150{ }^{\circ} \mathrm{C}$ as a result of the increase in the degree of hydrolysis of $\mathrm{ZnSO}_{4}$. As is known, it is difficult for metallic $\mathrm{Zn}$ to exist in acidic solutions, and this is consistent with there being no clear evidence in the AES results of the presence of metallic $\mathrm{Zn}$ on the surface of the Ru catalysts.
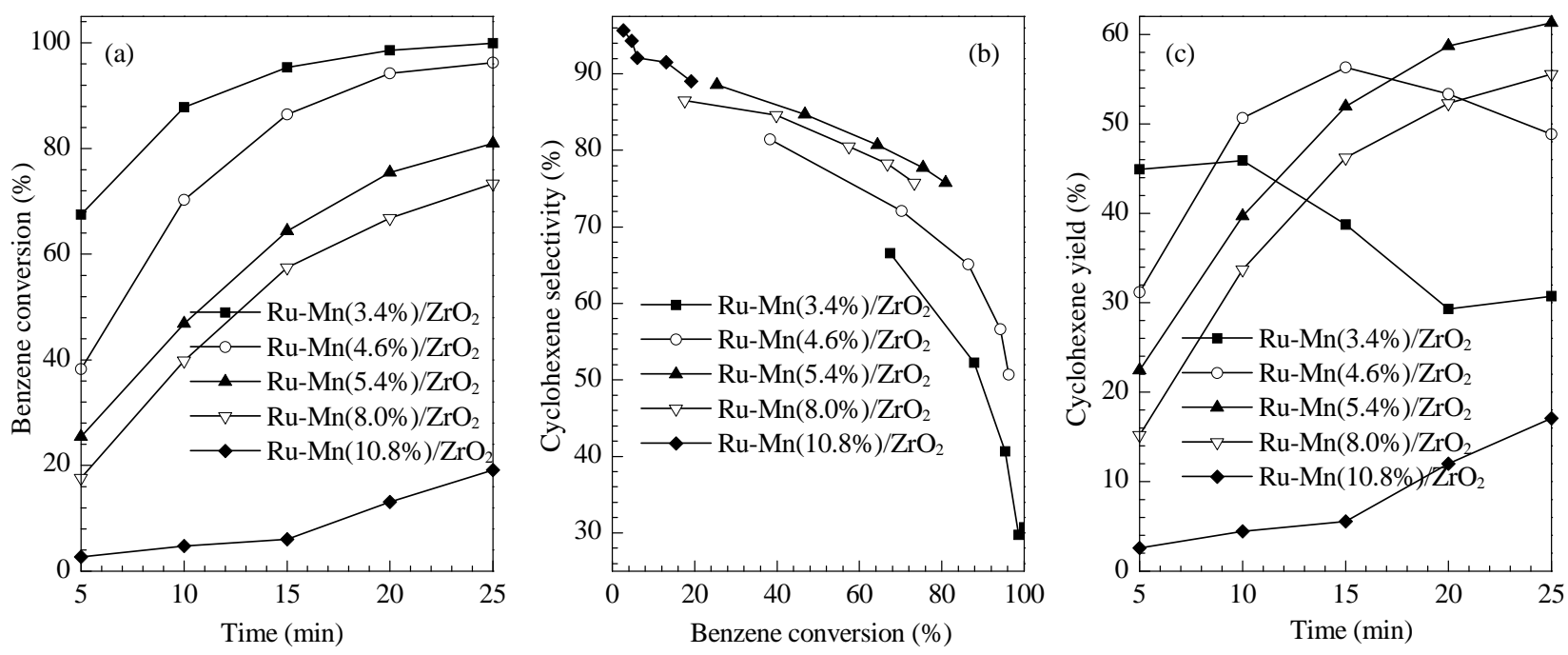

Fig. 4. Performance of $\mathrm{Ru}-\mathrm{Mn}(x) / \mathrm{ZrO}_{2}$ catalysts with different $\mathrm{Mn}$ contents for selective hydrogenation of benzene to cyclohexene. Reaction conditions: a share of $\mathrm{Ru}-\mathrm{Mn}(\mathrm{x})$ catalyst, $49.2 \mathrm{~g} \mathrm{ZnSO}_{4} \cdot 7 \mathrm{H}_{2} \mathrm{O}, 9.8 \mathrm{~g} \mathrm{ZrO}_{2}, 280 \mathrm{ml} \mathrm{H} \mathrm{O}_{2} 5 \mathrm{MPa} \mathrm{H}$, 150 ' $\mathrm{C}$, stirring rate $1400 \mathrm{r} / \mathrm{min}$. 

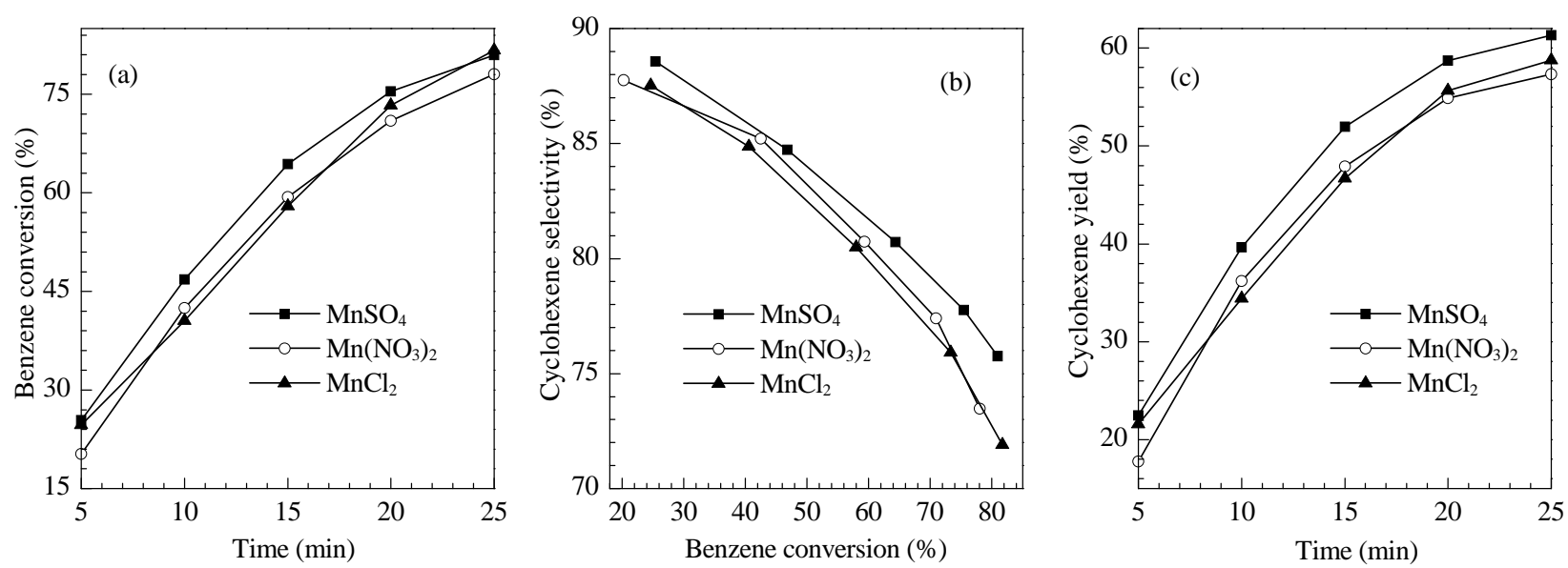

Fig. 5. Performence of $\mathrm{Ru}-\mathrm{Mn}(5.4 \%) / \mathrm{ZrO}_{2}$ catalysts prepared by different $\mathrm{Mn}$ precursors. Reaction conditions: a share of Ru-Mn( $\left.x\right)$ catalyst, $49.2 \mathrm{~g}$ $\mathrm{ZnSO}_{4} \cdot 7 \mathrm{H}_{2} \mathrm{O}, 9.8 \mathrm{~g} \mathrm{ZrO}_{2}, 280 \mathrm{ml} \mathrm{H} \mathrm{O}_{2}, 5 \mathrm{MPa} \mathrm{H}_{2}, 150{ }^{\circ} \mathrm{C}$, stirring rate $1400 \mathrm{r} / \mathrm{min}$.

To summarize, the Mn promoter in the $\mathrm{Ru}-\mathrm{Mn}(x)$ catalysts existed as $\mathrm{Mn}_{3} \mathrm{O}_{4}$ on the $\mathrm{Ru}$ surface. The $\mathrm{Mn}_{3} \mathrm{O}_{4}$ reacted with $\mathrm{ZnSO}_{4}$ to form the $\left[\mathrm{Zn}(\mathrm{OH})_{2}\right]_{3}\left(\mathrm{ZnSO}_{4}\right)\left(\mathrm{H}_{2} \mathrm{O}\right)_{3}$ salt in the hydrogenation process. This salt could be readily chemisorbed on the Ru surface and directly affected the performance of the Ru catalyst in the selective hydrogenation of benzene to cyclohexene.

\subsection{Performances of $R u-Z n(x)$ catalysts in selective hydrogenation of benzene to cyclohexene}

Figure 4 shows the performances of Ru-Mn $(x)$ catalysts with different $\mathrm{Mn}$ contents, using $\mathrm{ZrO}_{2}$ as a dispersant, for the selective hydrogenation of benzene to cyclohexene. As can be seen from Fig. 4(a) and (b), the catalytic activity increased and the cyclohexene selectivity at the same benzene conversion decreased with Mn content of the catalyst. Obviously, the increase in cyclohexene selectivity was achieved at the expense of catalytic activity. As can be seen from Fig. 4(c), the cyclohexene yields continuously increased when the Mn content of the catalyst increased from $3.4 \%$ to $5.4 \%$. However, with further increases in the Mn content, the cyclohexene yields increased gradually. The Ru-Mn(5.4\%) catalyst gave a cyclohexene yield of $61.3 \%$, which is among the best results reported so far $[9,29]$. It should also be noted that the Ru-Mn(5.4\%) catalyst without $\mathrm{ZrO}_{2}$ gave a cyclohexene selectivity of $82.7 \%$ at a benzene conversion of $59.4 \%$ at $15 \mathrm{~min}$. The activity was lower $(64.4 \%)$ and the cyclohexene selectivity was slightly higher (80.7\%) than those with $\mathrm{ZrO}_{2}$. This implied that the $\mathrm{ZrO}_{2}$ played an important role in dispersing the Ru catalyst particles; this is consistent with the TEM results.

The results described above show that the amount of $\left[\mathrm{Zn}(\mathrm{OH})_{2}\right]_{3}\left(\mathrm{ZnSO}_{4}\right)\left(\mathrm{H}_{2} \mathrm{O}\right)_{3}$ salt formed in the hydrogenation process increased with the $\mathrm{Mn}_{3} \mathrm{O}_{4}$ content of the $\mathrm{Ru}-\mathrm{Mn}(x)$ catalysts. The chemisorbed $\left[\mathrm{Zn}(\mathrm{OH})_{2}\right]_{3}\left(\mathrm{ZnSO}_{4}\right)\left(\mathrm{H}_{2} \mathrm{O}\right)_{3}$ salt played a key role in improving the cyclohexene selectivity of the Ru catalyst. (1) The chemisorbed $\left[\mathrm{Zn}(\mathrm{OH})_{2}\right]_{3}\left(\mathrm{ZnSO}_{4}\right)\left(\mathrm{H}_{2} \mathrm{O}\right)_{3}$ salt was rich in crystallization water. Chemisorption of the salt on the surface of the catalyst therefore resulted in the Ru catalyst being surrounded by a stagnant water layer. The existence of a stagnant water layer on the catalyst surface could accelerate desorption and hinder re-adsorption of cyclohexene for further hydrogenation to cyclohexane $[13,30]$. (2) The $\mathrm{Zn}^{2+}$ of the chemisorbed $\left[\mathrm{Zn}(\mathrm{OH})_{2}\right]_{3}\left(\mathrm{ZnSO}_{4}\right)\left(\mathrm{H}_{2} \mathrm{O}\right)_{3}$ salt could selectively cover most reactive sites of the catalyst, which could reduce the adsorption enthalpies of cyclohexene and benzene. A decrease in the adsorption enthalpy of cyclohexene could result in an increase in the cyclohexene desorption rate, and hence an increase in the cyclohexene selectivity. However, a decrease in the adsorption enthalpy of benzene would lead to a decrease in the catalytic activity $[24,30]$. (3) Electronic interactions between $\mathrm{Zn}^{2+}$ of the chemisorbed $\left[\mathrm{Zn}(\mathrm{OH})_{2}\right]_{3}\left(\mathrm{ZnSO}_{4}\right)\left(\mathrm{H}_{2} \mathrm{O}\right)_{3}$ salt and the active $\mathrm{Ru}$ components could modify the electronic structure of $\mathrm{Ru}$, which might be favorable for the formation of cyclohexene $[13,20,30]$. (3) The $\mathrm{Zn}^{2+}$ of the chemisorbed $\left[\mathrm{Zn}(\mathrm{OH})_{2}\right]_{3}\left(\mathrm{ZnSO}_{4}\right)\left(\mathrm{H}_{2} \mathrm{O}\right)_{3}$ salt could form loosely bound adducts with cyclohexene, which could stabilize the cyclohexene formed on the surface of the Ru catalyst and improve the cyclohexene selectivity $[9,20,29]$. The activities of the $\operatorname{Ru}-\operatorname{Mn}(x)$ catalysts therefore decreased and the cyclohexene selectivities increased with increasing amounts of chemisorbed $\left[\mathrm{Zn}(\mathrm{OH})_{2}\right]_{3}\left(\mathrm{ZnSO}_{4}\right)\left(\mathrm{H}_{2} \mathrm{O}\right)_{3}$ salt. The $\left[\mathrm{Zn}(\mathrm{OH})_{2}\right]_{3}\left(\mathrm{ZnSO}_{4}\right)\left(\mathrm{H}_{2} \mathrm{O}\right)_{3}$

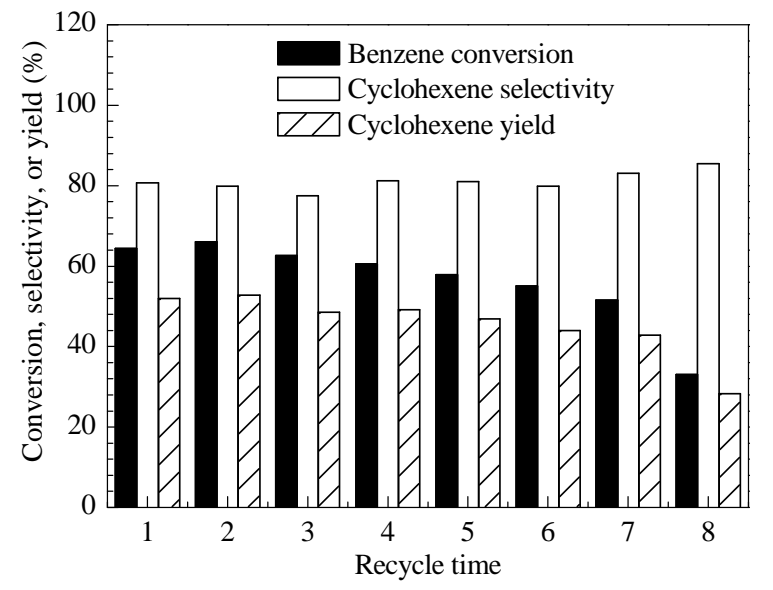

Fig. 6. Reusability of the $\mathrm{Ru}-\mathrm{Mn}(5.4 \%) / \mathrm{ZrO}_{2}$ catalyst for selective hydrogenation of benzene to cyclohexene. Reaction conditions: a share of $\mathrm{Ru}-\mathrm{Mn}(x)$ catalyst, $49.2 \mathrm{~g} \mathrm{ZnSO}_{4} \cdot 7 \mathrm{H}_{2} \mathrm{O}$, $9.8 \mathrm{~g} \mathrm{ZrO}_{2}, 280 \mathrm{ml} \mathrm{H}_{2} \mathrm{O}, 5 \mathrm{MPa} \mathrm{H}_{2}$, $150{ }^{\circ} \mathrm{C}$, stirring rate $1400 \mathrm{r} / \mathrm{min}$. 


\section{Graphical Abstract}

Chin. J. Catal., 2013, 34: 684-694 doi: 10.1016/S1872-2067(11)60489-0

\section{Selective hydrogenation of benzene to cyclohexene over nanocomposite $\mathrm{Ru}-\mathrm{Mn} / \mathrm{ZrO}_{2}$ catalysts}

SUN Haijie, JIANG Houbing, LI Shuaihui, WANG Hongxia, PAN Yajie, DONG Yingying, LIU Shouchang, LIU Zhongyi* Zhengzhou University

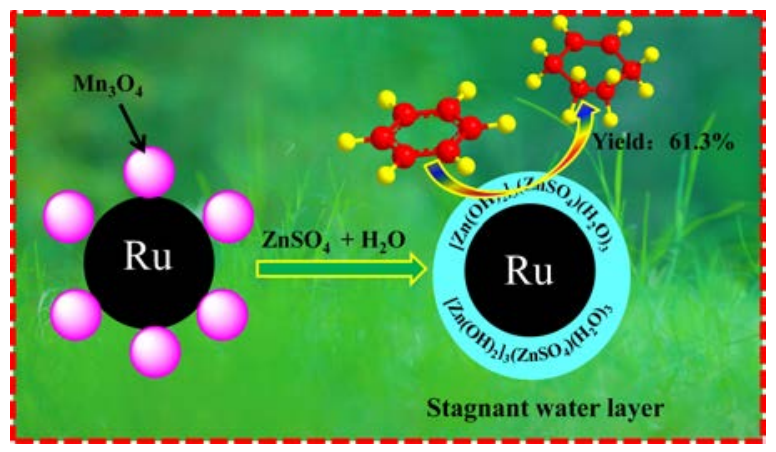

An Ru-Mn catalyst with an optimum Mn content of $5.4 \%$ gave a cyclohexene yield of $61.3 \%$. The chemisorbed $\left.\left[\mathrm{Zn}(\mathrm{OH})_{2}\right]_{3}(\mathrm{ZnSO})_{4}\right)\left(\mathrm{H}_{2} \mathrm{O}\right)_{3}$ salt, which was formed by the reaction of $\mathrm{Mn}_{3} \mathrm{O}_{4}$ with $\mathrm{ZnSO}_{4}$ in the slurry, improved the selectivity of the Ru catalyst.

salt chemisorbed on the Ru surface therefore played a decisive role in the enhancement of the cyclohexene selectivities of the Ru catalysts.

Figure 5 shows the performances of the $\operatorname{Ru}-\operatorname{Mn}(x)$ catalysts prepared using different precursors, with $\mathrm{ZrO}_{2}$ as a dispersant, for selective hydrogenation of benzene to cyclohexene. As can be seen, the activities, the cyclohexene selectivities, and the cyclohexene yields of these catalysts were all very similar. The characterization results confirmed that these catalysts had similar chemical compositions. This could be responsible for the very similar performances of these catalysts. The results also suggest that the $\mathrm{SO}_{4}{ }^{2-}, \mathrm{NO}_{3}{ }^{-}$, and $\mathrm{Cl}^{-}$ions of the Mn precursors had little effect on the performances of these catalysts.

Figure 6 shows the reusability of the Ru-Mn(5.4\%) catalyst with $\mathrm{ZrO}_{2}$. As can be seen, benzene conversion and cyclohexene selectivity were stable, at above $60.6 \%$ and $77.5 \%$, respectively, and the cyclohexene yields remained above $48.5 \%$ in the first four cycles. From the fifth cycle to the seventh cycle, the benzene conversion gradually decreased. However, benzene conversion was still above 50\%, and the cyclohexene selectivities and yields remained above $80 \%$ and $40 \%$, respectively. This indicates that $\mathrm{Ru}-\mathrm{Mn}(5.4 \%) / \mathrm{ZrO}_{2}$ had good stability and potential for industrial applications. The benzene conversion declined drastically to $33.1 \%$ in the eighth cycle. However, the cyclohexene selectivity remained as high as $85.4 \%$. The main reasons for the deactivation of the catalyst were the loss of catalyst and the absence of regeneration for long recycling times. Sulfur and nitrogen poisoning might also deactivate the catalyst [31].

\section{Conclusions}

That $\mathrm{Mn}$ in $\mathrm{Ru}-\mathrm{Mn}(x)$ catalysts existed as $\mathrm{Mn}_{3} \mathrm{O}_{4}$ on the $\mathrm{Ru}$ surface. The $\mathrm{Mn}_{3} \mathrm{O}_{4}$ could react with $\mathrm{ZnSO}_{4}$ in the slurry to form

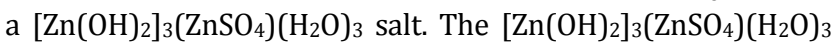

salt chemisorbed on the Ru surface played a key role in improving the cyclohexene selectivity of the $\mathrm{Ru}$ catalyst. These results indicate that some catalyst promoters could react with additives to form new substances. These new substances might significantly affect the selectivity and activity of the catalyst. This might provide new ideas for understanding the action mechanism of promoters in catalysis.

\section{References}

[1] Zhou X L, Sun H J, Guo W, Liu Zh Y, Liu Sh Ch.J Nat Gas Chem, 2011, 20: 53

[2] Wang W T, Liu H Zh, Wu T B, Zhang P, Ding G D, Liang Sh G, Jiang T, Han B X. J Mol Catal A, 2012, 355: 174

[3] Wang L J, Zhang A Q, Li L, Liu H F, Liu Sh Zh. Acta Chim Sin (王丽娟, 张爱清, 李琳, 刘汗范, 刘书正. 化学学报), 2012, 70: 1021

[4] Qin Y F, Xue W, Li F, Wang Y J, Wei J F. Chin J Catal (秦燕飞, 薛伟, 李芳, 王延吉, 魏珺芳. 催化学报), 2011, 32: 1727

[5] Sun H J, Guo W, Zhou X L, Chen Zh H, Liu Zh Y, Liu Sh Ch. Chin J Catal (孙海杰, 郭伟, 周小莉, 陈志浩, 刘仲毅, 刘寿长. 催化学报), 2011, 32: 1

[6] Xie S H, Qiao M H, Li H X, Wang W J, Deng J F. Appl Catal A, 1999, 176: 129

[7] Liu Sh Ch, Liu Zh Y, Wang Zh, Wu Y M, Yuan P. Chem Eng J, 2008, 139: 157

[8] Fan G Y, Jiang W D, Wang J B, Li R X, Chen H, Li X J. Catal Commun, 2008, 10: 98

[9] Liu J L, Zhu L J, Pei Y, Zhang J H, Li H, Li H X, Qiao M H, Fan K N. Appl Catal A, 2009, 353: 282

[10] Liu Sh Ch, Liu Zh Y, Wang Zh, Zhao Sh H, Wu Y M. Appl Catal A, 2006, 313: 49

[11] Sun H J, Zhang Ch, Yuan P, Li J X, Liu Sh Ch. Chin J Catal (孙海杰, 张 程, 袁鹏, 李建修, 刘寿长. 催化学报), 2008, 29: 441

[12] Liu Zh Y, Sun H J, Wang D B, Liu Sh Ch, Li Zh J. Chin J Chem, 2010, 28: 1927

[13] Sun H J, Zhang X D, Chen Zh H, Zhou X L, Guo W, Liu Zh Y, Liu Sh Ch. Chin J Catal (孙海杰, 张旭东, 陈志浩, 周小莉, 郭伟, 刘仲毅, 刘寿长. 
催化学报), 2011, 32: 224

[14] Liu Zh Y, Liu Sh Ch, Sun H J, Yuan X M, Yang K J, Zheng R, Wang M J, Li X X, Chen Zh H, Dong Y Y, Wang H X, Pan Y J, Li Sh H (刘仲毅, 刘 寿长, 孙海杰, 袁学民, 杨克俭, 郑仁, 王美娇, 李晓霞, 陈志浩, 董英 英, 王红霞, 潘雅洁, 李帅辉). CN 102600841 A. 2012

[15] Morales F, de Groot F M F, Glatzel P, Kleimeov E, Bluhm H, Hävecker M, Knop-Gericke A, Weckhuysen B M. J Phys Chem B, 2004, 108: 16201

[16] Xie Y Ch, Wang Ch B, Tang Y Q. Sci China (Ser B) (谢有畅, 汪传宝, 唐有祺. 中国科学: B 辑), 1993, 23: 113

[17] Nagahara H, Konishi M. US Patent 4734 536. 1988

[18] Zhang Y P, Wang X L, Shen K, Xu H T, Sun K Q, Zhou Ch Ch. Chin J Catal (张亚平, 汪小蕾, 沈凯, 徐海涛, 孙克勤, 周长城. 催化学报), 2012, 33: 1523

[19] Sun H J, Pan Y J, Wang H X, Dong Y Y, Liu Zh Y, Liu Sh Ch. Chin J Catal (孙海杰, 潘雅洁, 王红霞, 董英英, 刘仲毅, 刘寿长. 催化学报), 2012, 33: 610

[20] Wang J Q Wang Y Zh, Xie S H, Qiao M H, Li H X, Fan K N. Appl Catal A, 2004, 272: 29

[21] Yuan P Q, Wang B Q, Ma Y M, He H M, Cheng Zh M, Yuan W K.J Mol
Catal A, 2009, 301: 140

[22] He H M, Yuan P Q, Ma Y M, Cheng Zh M, Yuan W K. Chin J Catal (何 惠民, 袁佩青, 马悦铭, 程振民, 袁渭康. 催化学报), 2009, 30: 312

[23] Sun H J, Chen Zh H, Guo W, Zhou X L, Liu Zh Y, Liu Sh Ch. Chin J Chem, 2011, 29: 369

[24] Struijk J, Moene R, van der Kamp T, Scholten J J F. Appl Catal A, 1992, 89: 77

[25] Peplinski B, Unger W E S, Grohmann I. Appl Surf Sci, 1992, 62: 115

[26] Dai W L, Sun Q, Deng J F, Wu D, Sun Y H. Appl Surf Sci, 2001, 177: 172

[27] Silvestre-Albero J, Serrano-Ruiz J C, Sepúlveda-Escribano A, Rodríguez-Reinoso F. Appl Catal A, 2005, 292: 244

[28] Ramos-Fernández E V, Ferreira A F P, Sepúlveda-Escribano A, Kapteijn F, Rodríguez-Reinoso F. J Catal, 2008, 258: 52

[29] Liu J L, Zhu Y, Liu J, Pei Y, Li Zh H, Li H, Li H X, Qiao M H, Fan K N.J Catal, 2009, 268: 100

[30] Sun H J, Wang H X, Jiang H B, Li S H, Liu S C, Liu Z Y, Yuan X M, Yang K L. Appl Catal A, 2013, 450: 160

[31] Wu J M, Yang Y F, Chen J L. Chem Ind Eng Progr (吴济民, 杨炎锋, 陈 聚良. 化工进展), 2003, 22: 295

\section{纳米 $\mathrm{Ru}-\mathrm{Mn} / \mathrm{ZrO}_{2}$ 催化剂上苯选择加氢制环己烯 \\ 孙海杰, 江厚兵, 李帅辉, 王红霞, 潘雅洁, 董英英, 刘寿长, 刘仲毅* 郑州大学化学与分子工程学院，河南郑州 450001}

摘要: 采用共沉淀法制备了一系列不同 $\mathrm{Mn}$ 含量的纳米 $\mathrm{Ru}-\mathrm{Mn}$ 催化剂, 考察了纳米 $\mathrm{ZrO}_{2}$ 作分散剂时它们催化苯选择加氢制环己 烯的反应性能, 并采用 $\mathrm{X}$ 射线衍射、透射电镜、 $\mathrm{N}_{2}$ 物理吸附、 $\mathrm{X}$ 射线荧光、原子吸收光谱和俄歇电子能谱等手段对催化剂进行了 表征. 结果表明, $\mathrm{Ru}-\mathrm{Mn}$ 催化剂上 $\mathrm{Mn}$ 以 $\mathrm{Mn}_{3} \mathrm{O}_{4}$ 存在于 $\mathrm{Ru}$ 的表面上. 在加氢过程中, $\mathrm{Mn}_{3} \mathrm{O}_{4}$ 可以与浆液中 $\mathrm{ZnSO}_{4}$ 发生化学反应生成 一种难溶性的 $\left(\mathrm{Zn}(\mathrm{OH})_{2}\right)_{3}\left(\mathrm{ZnSO}_{4}\right)\left(\mathrm{H}_{2} \mathrm{O}\right)_{3}$ 盐. 该盐易化学吸附在 $\mathrm{Ru}$ 催化剂表面上, 从而在提高 $\mathrm{Ru}$ 催化剂上环已烯选择性起关键作 用. 当催化剂中 $\mathrm{Mn}$ 含量为 $5.4 \%$ 时,环已烯收率为 $61.3 \%$, 同时具有良好的稳定性和重复使用性能.

关键词: 苯; 选择加氢; 环已烯; 钓; 锰; 二氧化锆; 锌

收稿日期: 2012-10-10. 接受日期: 2012-11-20. 出版日期: 2013-04-20.

*通讯联系人. 电话: (0371)67783384; 电子信箱: liuzhongyi@zzu.edu.cn

基金来源: 国家自然科学基金 (21273205); 国家科技型中小企业创新基金 (10C26214104505); 中国博士后科学基金 (2012M511125); 郑州大学优秀博士论文培育基金.

本文的英文电子版由Elsevier出版社在ScienceDirect上出版(http://www.sciencedirect.com/science/journal/18722067)

\section{1. 前言}

由苯出发经环己烯制备尼龙-6 和尼龙-66 具有安 全、节能和环境友好的特点, 一直为人们所关注 ${ }^{[1 \sim 4]}$. 然而 在热力学上, 苯加氢更倾向于生成环己烷 ${ }^{[5]}$. 因此, 高选 择性苯加氢制环己烯催化剂的研发是该技术的核心.

以第二种金属或金属氧化物作助剂可显著提高 $\mathrm{Ru}$ 基催化剂上环己烯选择性和收率. Xie 等 ${ }^{[6]}$ 采用浸渍-化 学还原法制备了 $\mathrm{Ru}-\mathrm{B} / \mathrm{SiO}_{2}$ 催化剂, 其催化苯选择加氢 活性和环已烯选择性均比用 $\mathrm{H}_{2}$ 还原制得的 $\mathrm{Ru} / \mathrm{SiO}_{2}$ 的 高. 他们发现 $\mathrm{B}$ 以游离态和氧化态两种形式存在, 其对催 化剂表面的亲水性修饰是 $\mathrm{Ru}-\mathrm{B} / \mathrm{SiO}_{2}$ 催化剂表现出高活 性和高选择性的重要原因. Liu等 ${ }^{[7]}$ 用化学还原法制备 了 $\mathrm{Ru}-\mathrm{La}-\mathrm{B} / \mathrm{ZrO}_{2}$ 催化剂, 证实催化剂中的 $\mathrm{La}$ 以 $\mathrm{La}_{2} \mathrm{O}_{3}$ 存
在, 在苯加氢反应中环已烯收率和环已烯选择性分别达 $53.2 \%$ 和 $61.9 \%$. Fan 等 ${ }^{[8]}$ 用还原浸渍法制备了 $\mathrm{Ru}-\mathrm{Co}-\mathrm{B} / \gamma-\mathrm{Al}_{2} \mathrm{O}_{3}$ 催化剂, 证实催化剂中的 Co 以氧化钴 形式存在, 并在不加任何添加剂的条件下环己烯收率达 28.8\%. Liu 等 ${ }^{[9]}$ 用“双溶剂”浸渍法制备了 Ru-Ce/SBA-15 催化剂, 证实了 $\mathrm{Ce}$ 以 $\mathrm{Ce}(\mathrm{III})$ 物种存在, 当 $\mathrm{Ce} / \mathrm{Ru}$ 摩尔比 为 0.25 时环已烯收率为 $53.8 \%$. 这些研究工作为苯选择 加氢制环已烯催化体系的研发提供了有益的借鉴.

本课题组成功开发了苯选择加氢制环己烯 $\mathrm{Ru}-\mathrm{M}-\mathrm{B} / \mathrm{ZrO}_{2}(\mathrm{M}=\mathrm{Zn}, \mathrm{La}, \mathrm{Co}$ 和 Fe 等) 纳米非晶态合金催 化剂, 用比工业 Ru-Zn 催化剂少 $1 / 3$ 的 Ru, 获得了苯转化 率 59.6\% 时环己烯选择性 78.8\%, 优于工业 Ru-Zn 催化剂 (苯转化 $40 \%$ 时环己烯选择性 $80 \%)^{[10 ~ 12]}$. 目前, 本课题 组又成功开发了单层分散型苯选择加氢制环已烯 
Ru-M-Si (M = Zn, Mn, Fe, Ce 和 La 等) 催化剂, 苯转化率 $60 \%$ 时环已烯选择性达 $80 \%$ 以上. 该催化剂已实现工业 应用, 取得了良好的经济和社会效益, 并申报了国家发明 专利 ${ }^{[13,14]}$. 本文制备了一系列不同 Mn 含量的 Ru-Mn 催 化剂, 考察了 $\mathrm{Mn}$ 含量对苯选择加氢制环已烯 $\mathrm{Ru}$ 催化剂 性能的影响, 探讨了助剂 $\mathrm{Mn}$ 的作用机理, 并考察催化剂 的稳定性和循环使用性能.

\section{2. 实验部分}

\section{1. 催化剂制备}

将 $9.75 \mathrm{~g} \mathrm{RuCl}_{3} \cdot 3 \mathrm{H}_{2} \mathrm{O}$ 和一定量的 $\mathrm{MnSO}_{4} \cdot \mathrm{H}_{2} \mathrm{O}$ 溶于 蒸馏水中, 搅拌下加入 $10 \% \mathrm{NaOH}$ 溶液, 待充分反应后抽 滤. 所得黑色固体用清水洗涤三次, 然后分散于 5\% $\mathrm{NaOH}$ 溶液中, 转移至高压釜中还原. 在 $\mathrm{H}_{2}$ 压 $5.0 \mathrm{MPa}$ 、 $800 \mathrm{r} / \mathrm{min}$ 搅拌下升温至 $150^{\circ} \mathrm{C}$, 还原 $3 \mathrm{~h}$. 还原后取出, 用 蒸馏水洗涤至中性, 真空干燥, 即得 Ru-Mn催化剂. 平均 分为 2 份, 分别用于催化剂评价和表征, 确保用于加氢的 各催化剂中 $\mathrm{Ru}$ 含量相同. 调整 $\mathrm{MnSO}_{4} \cdot \mathrm{H}_{2} \mathrm{O}$ 用量, 得不同 $\mathrm{Mn}$ 含量的 Ru-Mn 催化剂, 记作 Ru-Mn $(x), x$ 为原子吸收 光谱测得的催化剂中 $\mathrm{Mn}$ 的质量百分含量. 以 $\mathrm{Mn}\left(\mathrm{NO}_{3}\right)_{2}$ 或 $\mathrm{MnCl}_{2}$ 为原料, 同法制得 $\mathrm{Ru}-\mathrm{Mn}(5.4 \%)$ 催化剂.

\section{2. 催化剂表征}

催化剂中 $\mathrm{Mn}$ 含量及加氢后浆液中 $\mathrm{Mn}^{2+}$ 和 $\mathrm{Zn}^{2+}$ 浓 度在 Heme Electron 公司 ICAT 6000 SERIES 型电感耦合 等离子体原子发射光谱仪 (ICP-AES) 上测定上测定. 催 化剂的物相分析在 PAN Nalytical 公司 X'Pert PRO 型 X 射线衍射 (XRD) 仪上进行. Cu $K_{\alpha}$ 射线, 管电压 $40 \mathrm{kV}$, 管 电流 $40 \mathrm{~mA}$, 扫描范围 $2 \theta=5^{\circ} \sim 90^{\circ}$, 扫描步长 $0.03^{\circ}$. 催化 剂的形貌在 JEOL JEM 2100 型透射电子显微镜 (TEM) 上 观察. 样品的织构性质在 Quantachrome 公司 Nova 1000e 型物理吸附仪上测定. 催化剂中各元素含量分析在 Bruker 公司 S4 Pioneer 型 X 射线苂光仪 (XRF) 上进行. Zn LMM 俄歇电子能谱在 ULVAC PHI-700 型纳米扫描 俄歇系统 (AES) 上测定, 电子枪高压为 $10 \mathrm{kV}$, 能量分辨 率为 $0.1 \%$, 入射角为 $30^{\circ}$, 分析室真空度为 $5.2 \times 10^{-7} \mathrm{~Pa}$. 以热氧化 $\mathrm{SiO}_{2} / \mathrm{Si}$ 为标样.

\section{3. 催化剂评价}

苯选择加氢反应在 GS-1 型哈氏合金釜中进行. 加 入一份 Ru-Mn 催化剂, $9.8 \mathrm{~g} \mathrm{ZrO}_{2}$, $49.2 \mathrm{~g} \mathrm{ZnSO}_{4} \cdot 7 \mathrm{H}_{2} \mathrm{O}$ 和 $280 \mathrm{ml} \mathrm{H}_{2}$. 在 $\mathrm{H}_{2}$ 压力为 $5.0 \mathrm{MPa}$ 和搅拌速率为 $800 \mathrm{r} / \mathrm{min}$ 的条件下, 升温至 $150{ }^{\circ} \mathrm{C}$ 后加入 $140 \mathrm{ml}$ 苯, 调节转速至 $1400 \mathrm{r} / \mathrm{min}$ (以消除外扩散), 每隔 $5 \mathrm{~min}$ 取样. 采用杭州科
晓 GC-1690 型气相色谱仪分析产物组成, FID 检测器, 面 积校正归一法计算产物浓度, 进而计算苯转化率和环己 烯选择性. 反应完成后, 用分液漏斗分离除去有机相, 催 化剂和 $\mathrm{ZrO}_{2}$ 连同反应浆液再次加入到高压反应釜中, 不 补加任何物质, 其它条件同上进行反应. 反应后固体样 品洗涤后留作表征. 加氢后固体样品记作 $\mathrm{Ru}-\mathrm{Mn}(x) / \mathrm{ZrO}_{2}, x$ 为原子吸收光谱测得的催化剂中 $\mathrm{Mn}$ 质量百分含量. 不加 $\mathrm{ZrO}_{2}$ 分散剂加氢后 $\mathrm{Ru}-\mathrm{Mn}(5.4 \%)$ 催 化剂记作 Ru-Mn(5.4\%) AH, AH 代表加氢后.

\section{3. 结果与讨论}

\section{1. 催化剂表征结果}

图 1 为 $\mathrm{Ru}-\mathrm{Mn}(x)$ 催化剂和 $\mathrm{Ru}-\mathrm{Mn}(x) / \mathrm{ZrO}_{2}$ 催化剂的 XRD 谱. 可以看出, 所有 Ru-Mn( $x$ ) 催化剂在 $2 \theta=38.5^{\circ}$, $42.3^{\circ}, 44.0^{\circ}, 58.3^{\circ}, 69.2^{\circ}, 78.4^{\circ}$ 和 $85.2^{\circ}$ 处出现了六方相金 属 $\mathrm{Ru}$ 的特征衍射峰 (JCPDS 01-070-0274). 其中 Ru-Mn(8.0\%) 和 Ru-Mn(10.8\%) 催化剂还在 $2 \theta=18.0^{\circ}$, $32.7^{\circ}, 36.1^{\circ}, 38.1^{\circ}, 58.9^{\circ}$ 和 $69.3^{\circ}$ 处出现了 $\mathrm{Mn}_{3} \mathrm{O}_{4}$ 的特征衍 射峰 (JCPDS 00-001-1127). Morales 等 ${ }^{[15]}$ 利用 $X$ 射线光 电子能谱 (XPS) 证实了在 $300^{\circ} \mathrm{C}$ 以下 $\mathrm{Mn}$ 主要以 $\mathrm{Mn}_{3} \mathrm{O}_{4}$ 形式存在. $\mathrm{Ru}-\mathrm{Mn}(x)$ 催化剂的还原温度为 $150{ }^{\circ} \mathrm{C}$, 因此 $\mathrm{Ru}-\mathrm{Mn}(x)$ 催化剂中 $\mathrm{Mn}$ 以 $\mathrm{Mn}_{3} \mathrm{O}_{4}$ 存在. 当 $\mathrm{Ru}-\mathrm{Mn}(x)$ 催化 剂中 $\mathrm{Mn}$ 含量为 $3.4 \% \sim 5.4 \%$ 时, 因为 $\mathrm{Mn}$ 含量较低, 且 $\mathrm{Mn}_{3} \mathrm{O}_{4}$ 微晶很小, 因而未发现 $\mathrm{Mn}_{3} \mathrm{O}_{4}$ 的特征衍射峰.

表 1 给出了利用最强衍射峰 $\left(2 \theta=44.0^{\circ}\right)$ 的半峰宽及 Scherrer 公式计算出催化剂中 $\mathrm{Ru}$ 的微晶尺寸. 由表可见, $\mathrm{Ru}$ 的微晶尺寸分布在 3.7 4.5 nm 很窄的范围内, 说明 $\mathrm{Mn}_{3} \mathrm{O}_{4}$ 的加入对 $\mathrm{Ru}$ 微晶尺寸的影响很小. 还可以看出, 加氢后所有 Ru-Mn(x)/ZrO 催化剂均出现弱的金属 $\mathrm{Ru}$ 的特征衍射峰 $\left(2 \theta=44.0^{\circ}\right)$, 说明金属 $\mathrm{Ru}$ 的微晶尺寸很小. 其余衍射峰均为单斜相 $\mathrm{ZrO}_{2}$ 的 (JCPDS 00-024-1165). 另 外, 不加 $\mathrm{ZrO}_{2}$ 时加氢后 Ru-Mn(5.4\%) 催化剂上不但出现 金属 $\mathrm{Ru}$ 的特征衍射峰, 而且在 $2 \theta=10.6^{\circ}, 14.7^{\circ}, 25.4^{\circ}$, $28.4^{\circ}$ 和 $32.8^{\circ}$ 处出现了 $\left[\mathrm{Zn}(\mathrm{OH})_{2}\right]_{3}\left(\mathrm{ZnSO}_{4}\right)\left(\mathrm{H}_{2} \mathrm{O}\right)_{3}$ (JCPDS01-078-0247) 的特征衍射峰. 这说明在 $\mathrm{ZnSO}_{4}$ 存 在下加氢后 $\mathrm{Ru}-\mathrm{Mn}(5.4 \%)$ 催化剂上生成了一种新的 $\left[\mathrm{Zn}(\mathrm{OH})_{2}\right]_{3}\left(\mathrm{ZnSO}_{4}\right)\left(\mathrm{H}_{2} \mathrm{O}\right)_{3}$ 盐. 然而, 加入 $\mathrm{ZrO}_{2}$ 后在所有 的 Ru-Mn $(x)$ 催化剂上并未发现该盐的衍射峰, 说明该盐 高度分散在金属 $\mathrm{Ru}$ 和分散剂 $\mathrm{ZrO}_{2}$ 的表面上. 谢有畅 等 ${ }^{[16]}$ 也证实盐可以在载体上自发分散.

图 2 给出了 $\mathrm{Ru}-\mathrm{Mn}(5.4 \%)$ 和 $\mathrm{ZrO}_{2}$ 作分散剂加氢后 $\mathrm{Ru}-\mathrm{Mn}(5.4 \%)$ 的 TEM 照片及其 Ru 微晶尺寸分布. 可以 
看出, Ru-Mn(5.4\%) 催化剂主要由圆形或椭圆形的 Ru 纳 米微晶组成, 其微晶尺寸主要集中在 $4.8 \mathrm{~nm}$ 左右, 与 $\mathrm{XRD}$ 结果一致. 由图 2(b) 可见, 分散剂 $\mathrm{ZrO}_{2}$ 主要由 $20 \mathrm{~nm}$ 左右的 $\mathrm{ZrO}_{2}$ 微晶组成. 经初次反应后催化剂颗粒被 $\mathrm{ZrO}_{2}$ 分隔开了. 这说明适量的 $\mathrm{ZrO}_{2}$ 可抑制反应过程中因催化 剂颗粒之间碰撞而聚结 ${ }^{[17]}$, 该催化剂中 $\mathrm{Ru}$ 的微晶尺寸 主要集中在 $4.5 \mathrm{~nm}$ 左右, 比加氢前的明显减小. 这说明 $\mathrm{ZrO}_{2}$ 对 $\mathrm{Ru}$ 催化剂颗粒起着分散作用.

表 1 还给出了各 $\operatorname{Ru}-\mathrm{Mn}(x)$ 催化剂的织构性能. 可以 看出, 随着 $\mathrm{Mn}$ 含量的增加, 催化剂的比表面积、孔径和 孔容均减小. 张亚平等 ${ }^{[18]}$ 同样发现, $\mathrm{MnO}_{x} / \mathrm{TiO}_{2}$ 催化剂的 比表面积比 $\mathrm{TiO}_{2}$ 的小, 认为是由于无定形 $\mathrm{MnO}_{x}$ 分散在 $\mathrm{TiO}_{2}$ 的表面并堵塞一部分孔所致. 这也可解释上述现象. 由于催化剂与 $\mathrm{ZrO}_{2}$ 的质量比为 $1: 5$, 加氢后 $\mathrm{Ru}-\mathrm{Mn}(x) / \mathrm{ZrO}_{2}$ 催化剂的织构性质与 $\mathrm{ZrO}_{2}$ 的相近 ${ }^{[19]}$. 因 此, 我们未对加氢后 $\mathrm{Ru}-\mathrm{Mn}(x) / \mathrm{ZrO}_{2}$ 催化剂进行 $\mathrm{N}_{2}$ 物理 吸附测定.

表 2 为 $\mathrm{ZrO}_{2}$ 作分散剂加氢后 $\mathrm{Ru}-\mathrm{Mn}(x)$ 催化剂的组 成和水相中金属离子浓度及其室温下的 $\mathrm{pH}$ 值. 需要特 别指出的是, 不同 $\mathrm{Mn}$ 含量的 $\mathrm{Ru}-\mathrm{Mn}(x)$ 中 $\mathrm{Ru}$ 含量相同, 因此 $\mathrm{Mn} / \mathrm{Ru}, \mathrm{Zn} / \mathrm{Ru}$ 和 $\mathrm{Zr} / \mathrm{Ru}$ 原子比随 $\mathrm{Mn}$ 含量的变化反 映了催化剂组成的变化. 用 $\mathrm{MnSO}_{4} \cdot \mathrm{H}_{2} \mathrm{O}$ 为前体制备了 不同 $\mathrm{Mn}$ 含量的 Ru-Mn(x) 催化剂. 由表 2 可见, 所有加氢 后 $\mathrm{Ru}-\mathrm{Mn}(x) / \mathrm{ZrO}_{2}$ 催化剂的 $\mathrm{Mn} / \mathrm{Ru}$ 原子比均为 0.02 , 说明 均只含有痕量的 $\mathrm{Mn}$. 随 $\mathrm{Mn}$ 含量增加, 加氢后 $\mathrm{Ru}-\mathrm{Mn}(x) / \mathrm{ZrO}_{2}$ 催化剂的 $\mathrm{Zn} / \mathrm{Ru}$ 原子比逐渐增加, 浆液中 $\mathrm{Mn}^{2+}$ 离子 (浆液为无色, 判定为 $\mathrm{Mn}^{2+}$ ) 浓度增加, $\mathrm{Zn}^{2+}$ 浓度 逐渐减小. 这说明 $\mathrm{Ru}-\mathrm{Mn}(x)$ 催化剂上 $\mathrm{Mn}_{3} \mathrm{O}_{4}$ 与浆液中 $\mathrm{ZnSO}_{4}$ 发生了化学反应, 生成了一种新的 $\mathrm{Zn}$ 物种和 $\mathrm{Mn}$ ( II ) 物种. 其中, Zn 物种化学吸附在 Ru催化剂表面, $\mathrm{Mn}$ ( II ) 物种溶解在浆液中. 不加 $\mathrm{ZrO}_{2}$ 加氢后 $\mathrm{Ru}-\mathrm{Mn}(5.4 \%)$ 上也只检测到痕量的 $\mathrm{Mn}$, 而 $\mathrm{Zn} / \mathrm{Ru}$ 原子比 与加 $\mathrm{ZrO}_{2}$ 加氢后的接近. 此外, 还检测到 $\mathrm{S} / \mathrm{Ru}$ 原子比为 0.06. 这与 $\mathrm{XRD}$ 检测到 $\mathrm{Zn}$ 物种以 $\left[\mathrm{Zn}(\mathrm{OH})_{2}\right]_{3}\left(\mathrm{ZnSO}_{4}\right)-$ $\left(\mathrm{H}_{2} \mathrm{O}\right)_{3}$ 盐存在一致. 分散剂 $\mathrm{ZrO}_{2}$ 的加入使 $\mathrm{Ru}-\mathrm{Mn}(x) / \mathrm{ZrO}_{2}$ 中 $\mathrm{S}$ 含量低于 XRF 的检测限而未能检测 到. 这说明 $\mathrm{Zn}$ 物种以 $\left[\mathrm{Zn}(\mathrm{OH})_{2}\right]_{3}\left(\mathrm{ZnSO}_{4}\right)\left(\mathrm{H}_{2} \mathrm{O}\right)_{3}$ 盐存在. 随着 $\mathrm{Mn}_{3} \mathrm{O}_{4}$ 含量增加, 生成的 $\left[\mathrm{Zn}(\mathrm{OH})_{2}\right]_{3}\left(\mathrm{ZnSO}_{4}\right)\left(\mathrm{H}_{2} \mathrm{O}\right)_{3}$ 盐增加, 故 $\mathrm{Zn} / \mathrm{Ru}$ 原子比逐渐增加. 而由此, 我们还可以 推断出 $\mathrm{Mn}_{3} \mathrm{O}_{4}$ 主要存在于 $\mathrm{Ru}$ 表面上, 因为浆液中的 $\mathrm{ZnSO}_{4}$ 只能与 $\mathrm{Ru}$ 表面上的 $\mathrm{Mn}_{3} \mathrm{O}_{4}$ 发生相互作用; 也就是 说, 生成的 $\left[\mathrm{Zn}(\mathrm{OH})_{2}\right]_{3}\left(\mathrm{ZnSO}_{4}\right)\left(\mathrm{H}_{2} \mathrm{O}\right)_{3}$ 盐也只能化学吸附
在 $\mathrm{Ru}$ 表面上. 此外, 随着 $\mathrm{Mn}$ 含量的增加, 加氢后水溶液 的 $\mathrm{pH}$ 值 (室温下) 升高. 浆液中 $\mathrm{Zn}^{2+}$ 浓度减小, 其水解程 度降低, 因此水溶液的 $\mathrm{pH}$ 逐渐上升. 因为 $\mathrm{ZrO}_{2}$ 的用量是 固定的, $\mathrm{Zr} / \mathrm{Ru}$ 原子比稳定在 5.00 左右.

分别用等物质量的 $\mathrm{MnSO}_{4}, \mathrm{Mn}\left(\mathrm{NO}_{3}\right)_{2}$ 和 $\mathrm{MnCl}_{2}$ 前体 制备了 $\mathrm{Ru}-\mathrm{Mn}(x)$ 催化剂, 原子吸收光谱测得 $\mathrm{Mn}$ 的质量 百分含量 $x$ 分别为 $5.4 \%, 5.2 \%$ 和 5.6\%. 由表 2 可见, 虽然 $\mathrm{Mn}$ 前体不同, 但加氢后的 $\mathrm{Ru}-\mathrm{Mn}(x) / \mathrm{ZrO}_{2}$ 催化剂的 $\mathrm{Mn} / \mathrm{Ru}, \mathrm{Zn} / \mathrm{Ru}$ 和 $\mathrm{Zr} / \mathrm{Ru}$ 原子比接近. 这说明加氢后催化 剂的化学组成近似.

化学吸附在 $\mathrm{Ru}$ 微晶表面的 $\mathrm{Zn}$ 物种起着提高 $\mathrm{Ru}$ 催

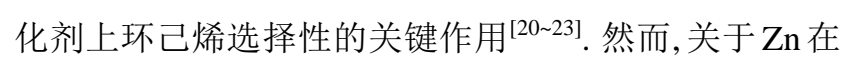
$\mathrm{Ru}$ 微晶表面的存在价态一直存在着较大的争议. Wang 等 ${ }^{[20]}$ 用氨水共沉淀 $\mathrm{RuCl}_{3}$ 和 $\mathrm{ZrOCl}_{2}$, 并在 $\mathrm{ZnSO}_{4}$ 溶液中 用 $\mathrm{H}_{2}$ 还原共沉淀产物制备了 $\mathrm{Ru}-\mathrm{Zn} / \mathrm{m}-\mathrm{ZrO}_{2}$ 催化剂. 他 们发现催化剂中 $\mathrm{Zn}$ 的 $\mathrm{Zn} 2 p_{3 / 2}$ 的电子结合能与金属 $\mathrm{Zn}$ 的接近, 认为部分 $\mathrm{ZnSO}_{4}$ 中的 $\mathrm{Zn}^{2+}$ 能够被从 $\mathrm{Ru}$ 表面上溢 流的 $\mathrm{H}$ 原子还原为金属 Zn. Yuan 等 ${ }^{[21]}$ 和何惠民等 ${ }^{[22]}$ 根 据 XPS 结果也认为, $\mathrm{Zn}^{2+}$ 能够被还原为金属 $\mathrm{Zn}$. 但 Stru$\mathrm{ijk}$ 等 ${ }^{[24]}$ 根据 XPS 结果认为, 化学吸附的 $\mathrm{Zn}^{2+}$ 不能被还 原为金属 Zn. 该争议的一个重要的原因是 $Z n(I I)$ 与金属 $\mathrm{Zn}$ 的 $\mathrm{Zn} 2 p_{3 / 2}$ 的电子结合能非常接近. 因此利用 $\mathrm{Zn} 2 p_{3 / 2}$ 的电子结合能的电子判定 $Z n$ 的价态是非常困难的 ${ }^{[25]}$. Zn LMM 俄歇电子跃迁已经解决了这个困难, 因为 $\mathrm{Zn}(\mathrm{II})$ 与金属 $\mathrm{Zn}$ 的俄歇位移高于 $4.6 \mathrm{eV}^{[26]}$. 图 3 给出了 $\mathrm{ZrO}_{2}$ 作分散剂加氢后 $\mathrm{Ru}-\mathrm{Zn}(5.4 \%)$ 催化剂的 Zn LMM 俄 歇电子能谱. 需要特别指出的是, 为避免表面氧化的干 扰, 该谱图是在用 $\mathrm{Ar}^{+}$溅射 $1 \mathrm{~min}$ 后被记录下来的. 可以看 出, 加氢后 $\mathrm{Ru}-\mathrm{Zn}(5.4 \%) / \mathrm{ZrO}_{2}$ 的 $\mathrm{Zn} \mathrm{LMM}$ 的俄歇电子动 能为 $984.2 \mathrm{eV}$, 与 $\mathrm{Zn}(\mathrm{II})$ 的一致 ${ }^{[27,28]}$, 也与 $\mathrm{XRD}$ 结果一 致. 同时还说明了化学吸附在 $\mathrm{Ru}$ 表面上的 $\mathrm{Zn}$ 即使在 $150{ }^{\circ} \mathrm{C}$ 和 $\mathrm{H}_{2}$ 压 $5 \mathrm{MPa}$ 下仍以 $\mathrm{Zn}^{2+}$ 存在. $\mathrm{Zn}$ LMM AES 谱 没有给出任何金属 $\mathrm{Zn}$ 的信号 (金属 Zn 的 Zn LMM 俄歇 电子动能一般在 991 995 eV), 说明化学吸附在 Ru 表面 的 $\mathrm{Zn}^{2+}$ 不能被还原为金属 $\mathrm{Zn}$. 表 2 给出的加氢后室温下 水相的 $\mathrm{pH}$ 值呈酸性是由于 $\mathrm{ZnSO}_{4}$ 的水解. 温度升高有 利于水解程度增加, 因此在 $150^{\circ} \mathrm{C}$ 反应水相的酸性会更 强. 金属 $\mathrm{Zn}$ 在酸性溶液中是很难存在的, 与 AES 谱上没 有发现金属 Zn 的信号一致.

总之, $\mathrm{Ru}-\mathrm{Mn}(x)$ 催化剂上 $\mathrm{Mn}$ 以 $\mathrm{Mn}_{3} \mathrm{O}_{4}$ 存在于 $\mathrm{Ru}$ 表 面上. 在加氢过程中, $\mathrm{Mn}_{3} \mathrm{O}_{4}$ 可以与浆液中的 $\mathrm{ZnSO}_{4}$ 反应 生成一种 $\left[\mathrm{Zn}(\mathrm{OH})_{2}\right]_{3}\left(\mathrm{ZnSO}_{4}\right)\left(\mathrm{H}_{2} \mathrm{O}\right)_{3}$ 盐. 该盐易化学吸附 
在 $\mathrm{Ru}$ 表面上, 直接影响 $\mathrm{Ru}$ 催化剂的苯选择加氢制环己 烯性能.

\section{2. 苯选择加氢制环己烯 $\mathrm{Ru}-\mathrm{Mn}(x) / \mathrm{ZrO}_{2}$ 催化剂性能}

图 4 给出了 $\mathrm{ZrO}_{2}$ 作分散剂不同 $\mathrm{Mn}$ 含量 $\mathrm{Ru}-\mathrm{Mn}(x)$ 催化剂的苯选择加氢制环己烯性能. 可以看出, 随着 $\mathrm{Mn}$ 含量的增加, 催化剂活性逐渐降低, 相同转化率下环己烯 选择性逐渐升高. 可见, 选择性的升高是以牺牲活性为 代价的. 还可以看出, Mn 含量从 3.4\% 增加到 5.4\% 时, 环 己烯收率逐渐增加至 $61.3 \%$. 这是目前报道最好结果之 一 ${ }^{[9,29]}$. 继续增加 $\mathrm{Mn}$ 含量, 环己烯收率下降. 此外, 不加 分散剂 $\mathrm{ZrO}_{2}$ 的 $\mathrm{Ru}-\mathrm{Mn}(5.4 \%)$ 催化剂上反应 $15 \mathrm{~min}$ 苯转 化 59.4\% 时环已烯选择性为 $82.7 \%$. 不添加的活性比添 加的 (64.4\%) 低, 环已烯选择性比添加的 (80.7\%)略高, 说 明了 $\mathrm{ZrO}_{2}$ 对 $\mathrm{Ru}$ 催化剂颗粒起着分散作用, 与 TEM 结果 一致.

由以上表征可知, 随 $\mathrm{Ru}-\mathrm{Mn}(x)$ 催化剂上 $\mathrm{Mn}_{3} \mathrm{O}_{4}$ 的增 加, 在加氢过程生成的 $\left[\mathrm{Zn}(\mathrm{OH})_{2}\right]_{3}\left(\mathrm{ZnSO}_{4}\right)\left(\mathrm{H}_{2} \mathrm{O}\right)_{3}$ 盐逐渐 增加. 化学吸附在 Ru 表面上的 $\left[\mathrm{Zn}(\mathrm{OH})_{2}\right]_{3}\left(\mathrm{ZnSO}_{4}\right)\left(\mathrm{H}_{2} \mathrm{O}\right)_{3}$ 盐起着提高 $\mathrm{Ru}$ 催化剂上环已烯选择性的关键作用. (1) 该盐含有丰富的结晶水, 可以在 $\mathrm{Ru}$ 表面上形成一层滞水 层, 加速生成的环已烯从 $\mathrm{Ru}$ 表面上脱附, 并抑制环已烯 再吸附到催化剂表面继续加氢生成环已烷 ${ }^{[13,30]}$. (2) 该盐 可以占据一部分活性最高的活性位, 降低环已烯和苯的 吸附焓, 从而降低导致环己烯脱附速率的增加, 使得环己 烯选择性升高, 同时也使得催化剂的活性降低 ${ }^{[24,30]}$. (3) 该盐中的 $\mathrm{Zn}^{2+}$ 与活性组分 $\mathrm{Ru}$ 之间的电子相互作用使 $\mathrm{Ru}$ 的电子结构有利于环已烯的生成 ${ }^{[13,20,30]}$. (4) 该盐的 $\mathrm{Zn}^{2+}$ 可以与环己烯形成松散的键合物,可以稳定 $\mathrm{Ru}$ 表面上形 成的环己烯, 进而提高其选择性 ${ }^{[9,20,29]}$. 因此, 化学吸附的 $\left[\mathrm{Zn}(\mathrm{OH})_{2}\right]_{3}\left(\mathrm{ZnSO}_{4}\right)\left(\mathrm{H}_{2} \mathrm{O}\right)_{3}$ 盐的增加使得 Ru-Mn( $\left.x\right) / \mathrm{ZrO}_{2}$
催化剂的活性降低,环己烯选择性升高. 总之, 它在提高 $\mathrm{Ru}$ 催化剂环己烯选择性中起着决定性作用.

图 5 给出了 $\mathrm{ZrO}_{2}$ 作分散剂不同前体制备的 Ru-Mn(5.4\%) 催化剂上苯选择加氢制环己烯性能. 可以 看出, 不同 $\mathrm{Mn}$ 前体制备的 $\mathrm{Ru}-\mathrm{Mn}(5.4 \%) / \mathrm{ZrO}_{2}$ 催化剂活 性、环己烯选择性和收率接近. 表征结果证实了这些 Ru-Mn(5.4\%)/ZrO 催化剂的化学组成接近, 因而在催化 苯选择加氢制环已烯反应中催化性能接近, 同时这也说 明了 $\mathrm{Mn}$ 前体的 $\mathrm{SO}_{4}{ }^{2-}, \mathrm{NO}_{3}{ }^{-}$和 $\mathrm{Cl}^{-}$对 $\mathrm{Ru}$ 催化剂性能的影 响很小.

图 6 为 $\mathrm{ZrO}_{2}$ 作分散剂时 Ru-Mn(5.4\%) 催化剂的循 环使用性能. 可以看出, 前 4 次循环使用中, 苯转化率稳 定在 $60.6 \%$ 以上, 环已烯选择性稳定在 $77.5 \%$ 以上, 环已 烯收率稳定在 $48.5 \%$. 从第 5 次循环到第 7 次时, 虽然苯 转化率逐渐降低, 但仍在 $50 \%$ 以上, 环已烯选择性和收 率分别保持在 $80 \%$ 和 $40 \%$ 以上. 可见, Ru-Mn(5.4\%)/ $\mathrm{ZrO}_{2}$ 催化剂的稳定性好, 具有良好的工业应用前景. 循 环使用至第 8 次时, 苯转化率急剧降低至 $33.1 \%$, 然而环 己烯选择性仍高达 $85.4 \%$. 这主要是由于催化剂在循环 使用过程中损失和长时间循环使用未再生引起的. 此外, $\mathrm{S}$ 和 $\mathrm{N}$ 中毒也可能是催化剂失活的原因 ${ }^{[31]}$.

\section{4. 结论}

$\mathrm{Ru}-\mathrm{Mn}(x)$ 催化剂中的 $\mathrm{Mn}$ 以 $\mathrm{Mn}_{3} \mathrm{O}_{4}$ 存在于 $\mathrm{Ru}$ 的表 面上. 加氢过程中助剂 $\mathrm{Mn}_{3} \mathrm{O}_{4}$ 与浆液中 $\mathrm{ZnSO}_{4}$ 反应生成 了一种 $\left[\mathrm{Zn}(\mathrm{OH})_{2}\right]_{3}\left(\mathrm{ZnSO}_{4}\right)\left(\mathrm{H}_{2} \mathrm{O}\right)_{3}$ 盐, 它化学吸附在 $\mathrm{Ru}$ 表 面上,在提高 $\mathrm{Ru}$ 催化剂上环己烯选择性中起着决定性作 用. 这表明有些催化剂中助剂可以与添加剂反应生成一 种新的物质, 从而可能直接影响催化剂的选择性或活性, 有利于深入理解助剂的作用. 